\title{
Contemporary and historical patterns of connectivity among populations of an inland river fish species inferred from genetics and otolith chemistry
}

\author{
Ryan J. Woods, Jed I. Macdonald, David A. Crook, Daniel J. Schmidt, and \\ Jane M. Hughes
}

\begin{abstract}
Patterns of dispersal in riverine populations of Australian smelt (Retropinna semoni) were examined using otolith chemistry (Mg:Ca, Mn:Ca, Sr:Ca, Ba:Ca) and genetic markers (allozymes, mtDNA, microsatellite DNA). During a period of prolonged low flows, young-of-year smelt were collected from 13 streams within three catchments of the southern Murray-Darling Basin, Australia. Spatial differences in otolith core and edge chemical signatures and high levels of genetic assignment to sampling locations were observed, suggesting that most recruits were retained in natal areas after spawning. Following a subsequent period of hydrological connection, the same cohort was sampled as 1-year-olds. Maximum likelihood estimation using otolith core chemistry data from these fish suggested that retention in natal areas was highly variable between years and a similar, though less pronounced, pattern was evident in genetic assignments. Partitioning of genetic variation among catchments was not significant $\left(F_{\mathrm{CT}}<0.004\right)$ and probably reflects disequilibrium between migration and genetic drift due to an historical population expansion ( 270000 years ago). Taken together, otolith chemistry and genetic analyses suggest that contemporary dispersal of smelt within these catchments is relatively restricted and may be mediated by changes in hydrological connectivity.
\end{abstract}

Résumé : Des analyses de la chimie des otolithes (Mg:Ca, $\mathrm{Mn}: \mathrm{Ca}, \mathrm{Sr}: \mathrm{Ca}, \mathrm{Ba}: \mathrm{Ca}$ ) et des marqueurs génétiques (allozymes, $\mathrm{ADNmt}, \mathrm{ADN}$ des microsatellites) nous ont servi à examiner les patrons de dispersion des populations de rivière de l'éperlan australien (Retropinna semoni). Durant une période prolongée de débits réduits, nous avons récolté des jeunes éperlans de l'année dans 13 cours d'eau dans trois bassins du réseau hydrographique sud des fleuves Murray-Darling, Australie. Nous avons observé des différences spatiales dans les signatures chimiques du noyau et de la périphérie des otolithes et de forts niveaux d'assignation génétique aux stations d'échantillonnage, ce qui indique que la plupart des recrues restent dans les zones natales après la fraie. Nous avons échantillonné la même cohorte à l'âge de 1 an après une période subséquente de connexion hydrologique. Une estimation de vraisemblance maximale faite sur les données de chimie du noyau des otolithes chez ces poissons indique que la rétention dans les aires de naissance est très variable d'une année à l'autre; il existe un patron semblable, bien que moins prononcé, dans les assignations génétiques. Le partitionnement de la variation génétique entre les bassins n'est pas significatif $\left(F_{\mathrm{CT}}<0,004\right)$ et reflète probablement le déséquilibre entre la migration et la dérive génétique causé par une expansion de la population dans le passé (il y a 270 000 ans). En combinaison, les analyses chimiques des otolithes et les analyses génétiques laissent croire que la dispersion actuelle des éperlans dans ces réseaux hydrographiques est relativement restreinte et peut s'expliquer par les changements dans la connectivité hydrologique.

[Traduit par la Rédaction]

Received 17 June 2009. Accepted 6 April 2010. Published on the NRC Research Press Web site at cjfas.nrc.ca on 15 June 2010. J21264

Paper handled by Associate Editor Eric Taylor.

R.J. Woods. ${ }^{1}$ Australian Rivers Institute, Griffith University, Nathan, 4111, Queensland, Australia.

J.I. Macdonald. Arthur Rylah Institute for Environmental Research, Department of Sustainability and Environment, 123 Brown Street, Heidelberg, 3084, Victoria, Australia.

D.A. Crook. Arthur Rylah Institute for Environmental Research and eWater CRC, Department of Sustainability and Environment, 123 Brown Street, Heidelberg, 3084, Victoria, Australia.

D.J. Schmidt ${ }^{2}$ and J.M. Hughes. Australian Rivers Institute and eWater CRC, Griffith University, Nathan, 4111, Queensland, Australia.

${ }^{1}$ Present address: Aquatic Ecosystems Unit, Department of Natural Resources and Water, 120 Meiers Road Indooroopilly, Queensland, 4068, Australia.

${ }^{2}$ Corresponding author (e-mail: d.schmidt@griffith.edu.au). 


\section{Introduction}

Rivers are dendritic environments characterized by networks of hierarchically arranged habitat patches in which hydrologic and biotic connectivities are often temporally and spatially variable (Fagan 2002; Grant et al. 2007). Considering the changes to hydrology predicted to occur as a result of anthropogenic climate change and increased human demands for water resources (Miles et al. 2000; Mimikou et al. 2000; Commonwealth Scientific and Industrial Research Organisation (CSIRO) and Australian Bureau of Meteorology 2007), questions regarding the role of dispersal in the persistence of riverine organisms are of increasing importance to the conservation of aquatic biodiversity (Hughes 2007; Lassalle et al. 2008).

The behavioural and physical processes that influence connectivity for a given species operate over a range of temporal scales, from events within the lifetime of an individual (e.g., floods, droughts) to evolutionary time scales (e.g., ice ages, geological eras). A variety of methodological approaches are now available to examine biotic connectivity over these time scales (Lucas and Baras 2000). For example, analysis of the chemical constituents of fish otoliths (ear stones) has recently been used to examine within-lifetime patterns of connectivity among fish populations (e.g., Thorrold et al. 2001; Gillanders 2002; Crook and Gillanders 2006). The otoliths of fish grow continuously throughout life and are composed of a calcium carbonate matrix that is not remetabolized once deposited (Campana 1999). Dissolved trace elements in the surrounding water become chemically bonded within the otolith matrix as it accretes, and the concentrations of trace elements can thus be used to characterize the ambient water chemistry at different stages of life, including recent growth at the otolith edge and early life stages at the otolith core (Forrester and Swearer 2002; Gillanders and Joyce 2005; Sandin et al. 2005). By comparing the natal signatures of fish within a population, it is possible to estimate the recruitment sources of individuals and levels of connectivity between populations (Thorrold et al. 2001; Ruttenberg and Warner 2006; Barbee and Swearer 2007).

The use of genetic methods, in particular the analysis of variation in allozymes, mitochondrial DNA, and microsatellite DNA, is also well established in studies of population structure and dispersal in freshwater fish (Avise 2004). Various models of population structure that capture major differences in connectivity of river networks have been adopted (Hughes et al. 2009). For example, the stream hierarchy model (SHM; Meffe and Vrijenhoek 1988) predicts that the hierarchical structuring of a river network will covary with genetic structure because gene flow is more likely to occur between populations that are nested together in the river network. Where these models fail to account for observed data, other models that do not assume equilibrium between migration and genetic drift may be useful for inferring regional patterns of dispersal. These relate the degree of geographic separation among populations with their genetic differentiation (Slatkin 1993; Hutchison and Templeton 1999). In addition, dispersal estimates can be obtained using individual assignment methods that test whether an individual is a member of a particular breeding population based on the likelihood of its multilocus genotype arising by random mating in a given population of genotypes (Manel et al. 2005). Provided that sufficient genetic differentiation exists among populations, such an approach can be used to classify an individual as a "resident" or "immigrant" to its population of origin (Paetkau et al. 2004). By employing the range of available genetic techniques in such ways, analysis of population genetics can provide estimates of dispersal over time scales ranging from the lifetime of an individual fish to millennia.

Most previous studies of connectivity and structure among fish populations have used methods such as otolith chemistry and genetic techniques in isolation. More recently, however, researchers have begun to recognise the potential to increase inference by combining techniques to obtain independent estimates of population structure. Miller et al. (2005), for example, used otolith chemistry and microsatellite data to show that populations of the marine black rockfish (Sebastes melanops) exhibit localized spatial structuring. Similarly, identification of distinct population subdivisions was corroborated by otolith and microsatellite data in fluvial populations of Arctic grayling (Thymallus arcticus; Stamford and Taylor 2005; Clarke et al. 2007), Sacramento splittail (Pogonichthys macrolepidotus; Baerwald et al. 2007; Feyrer et al. 2007), and stocks of Chinook salmon (Oncorhynchus tshawytscha; Miller et al. 2010). Based on microsatellite data, limited broad-scale dispersal was inferred for northern hemisphere rainbow smelt $(\mathrm{Os}$ merus mordax) populations, and otolith analysis confirmed that most rainbow smelt remain in estuaries during their first year of life (Bradbury et al. 2008).

Although combined analyses of otolith chemistry and genetic data often provide complementary information, in some cases there are apparent conflicts between estimates of population structure using the two methods. For example, several otolith chemistry analyses have revealed high levels of local recruitment in some marine fish, whereas genetic analysis indicated little evidence for population structure (Swearer et al. 1999 cf. Haney et al. 2007; Thorrold et al. 2001). These differences have been explained by recognising that patterns of genetic variation are contingent on a variety of processes (e.g., population size and history) in addition to the contemporary pattern of spatial connectivity that is resolved by otolith chemistry data. The chronological properties of otoliths can provide a record of movements between different aquatic environments within the lifetime of an individual, whereas genetic markers may resolve population structure over various time scales depending on the rate that variation accumulates at a given locus.

The aim of the present study was to use a suite of genetic and otolith chemistry techniques to investigate the population structure of a small fish species, the Australian smelt (Retropinna sp.), in small ephemeral waterways. The stochastic nature of ephemeral river systems impose spatial and temporal limits on population connectivity because opportunities for dispersal and gene flow are restricted to periods when flow is sufficient to allow movement between refugial pools. Additionally, the temporal and spatial patchiness of water in ephemeral systems renders their fish faunas highly vulnerable to the predicted impacts of climatic change, particularly in regions experiencing increased aridity. For example, hydrological connectivity may be funda- 
mentally altered by reduced flows in the future, with likely consequences for the demography of species such as the Australian smelt. Within this context, we examine spatial variation in otolith chemistry and genetic data of Australian smelt to elucidate contemporary patterns of population structure and historical and contemporary processes relating to connectivity between hydrologically isolated populations. Specifically, we set out to determine $(i)$ whether results of the two techniques indicate similar levels of contemporary dispersal in riverine populations of the Australian smelt, and (ii) whether Australian smelt populations are panmictic, reflecting widespread migration within the system, or fit the stream hierarchy model, with populations from the same river more similar than populations from different rivers.

\section{Materials and methods}

\section{Study species}

The Australian smelt is a common and abundant smallbodied (<100 mm total length) freshwater fish species complex, widely distributed throughout coastal and inland drainages in southeastern Australia. It is a member of the family Retropinnidae (southern smelts), which share a close evolutionary relationship with northern hemisphere Osmeridae (northern smelts) and southern Galaxiidae (Waters et al. 2002). Species in these groups exhibit a range of diadromous and wholly freshwater life history strategies (McDowall 1988). The Australian Retropinna are short-lived fish (up to 3 years), represented by two recognised species, including the widely distributed Retropinna semoni (Weber) in eastern Australia and Retropinna tasmanica (McCulloch) in Tasmania. Hammer et al. (2007) recently highlighted the need for taxonomic reappraisal of Australian Retropinna by demonstrating a pattern of cryptic diversity more consistent with the presence of five species. Population-level analyses indicate that $R$. semoni from the upper Murray-Darling Ba$\sin$ (MDB) (including the location of the present study) comprise a genetically homogenous group (MTV taxon after Hammer et al. 2007). The present analysis is therefore unlikely to be compromised by inclusion of multiple cryptic taxa, and we hereafter refer to the study species as Australian smelt or smelt. There is little detailed knowledge of the extent of movements by the species, although potamodromous migrations within freshwater have been reported in several studies of fish passing through fish ladders (e.g., Mallen-Cooper 1999; Baumgartner 2004). At least some coastal populations are thought to display facultative diadromy, with some larvae and early juveniles spending time in the estuarine or marine environment before undertaking upstream migrations into freshwater (Crook et al. 2008). There is no possibility that the smelt sampled in the current study had spent time in the marine environment, however, as the mouth of the Murray River (into which the study streams ultimately flow) is more than $1500 \mathrm{~km}$ downstream, with multiple dams and weirs acting as complete migration barriers along this distance.

\section{Sampling sites}

Smelt were collected from 12 ephemeral tributaries of the catchments of the Ovens, Campaspe, and Goulburn rivers in the southern MDB, southeastern Australia. A single site on
Fig. 1. Locations of collection sites within the Campaspe, Goulburn, and Ovens catchments. Solid stars represent sites in the Campaspe catchment (CR, Campaspe River; FC, Forest Creek; MC, McIvor Creek). Shaded circles represent sites in the Goulburn catchment (BR, Broken River; SE, Seven Creeks; CA, Castle Creek; RL, Reedy Lake Creek; SC, Sugarloaf Creek; DC, Dabyminga Creek; GL, Glen Creek). Shaded triangles represent sites in the Ovens catchment (RC, Reedy Creek; CC, Castle Creek; HC, Hurdle Creek).

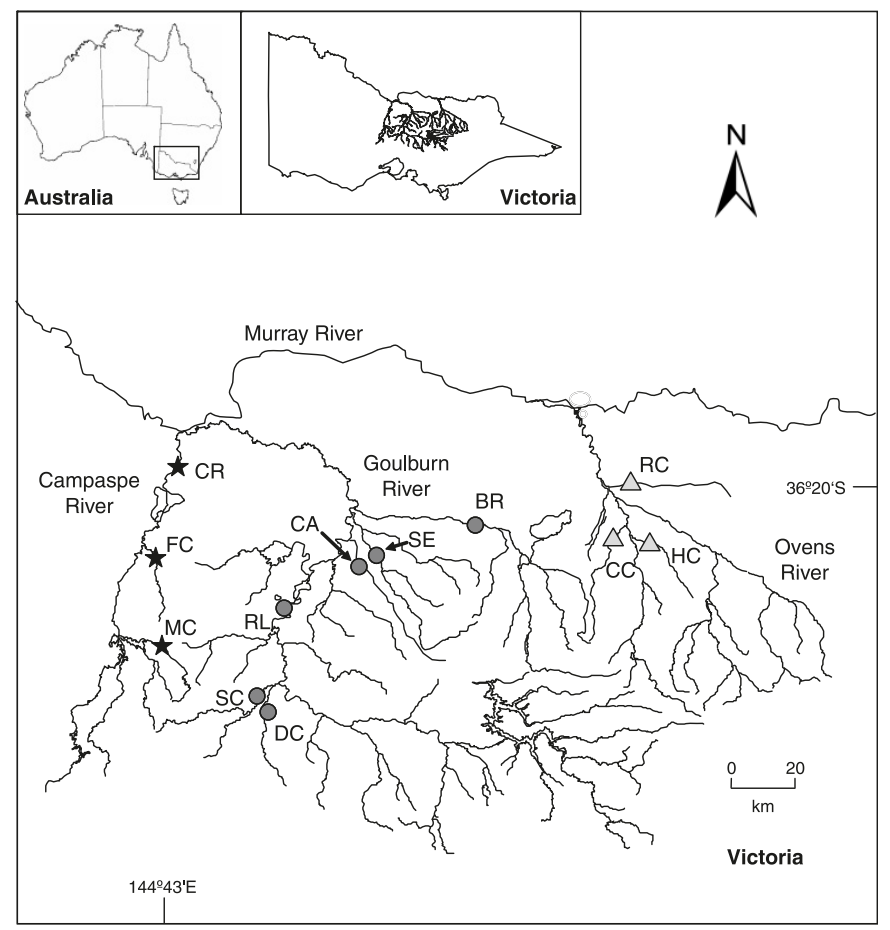

the main channel of the Campaspe River was also sampled (Fig. 1). The Ovens River is one of the least flow-regulated rivers in the MDB, and although there are several small dams in the upper reaches of the catchment (total catchment area, 798100 ha), a relatively natural flow regime is maintained throughout the year. Within the Campaspe (404 800 ha) and the larger Goulburn (1685700 ha) catchments, substantial barriers to movement (dams and weirs) have been constructed since European settlement, and flow is heavily regulated. The tributaries that we sampled typically experience periods of low flow in the summer months, resulting in a series of hydrologically disconnected pools that act as refugial habitat for fish. Such conditions were evident in all three catchments for several months preceding sampling in February 2004 and February 2005. However, in the intervening period during winter and spring 2004 (June to November), increased flows temporarily restored hydrologic connectivity between pools in all of the study tributaries.

\section{Fish collection}

Young-of-year (YOY) and 1-year-old smelt were collected using a $1.5 \mathrm{~m} \times 7 \mathrm{~m}$ fine-mesh seine net in February 2004. In 2005, 1-year-old smelt (i.e., the 2004 YOY cohort) were collected for otolith chemistry analysis to allow us to estimate dispersal following re-establishment of hydrological connectivity in the tributaries during spring and winter 2004. A random sample of YOY and 1-year-old individuals were 
used for genetic analysis in both 2004 and 2005. Upon capture, each fish was euthanized in an ice slurry and dissected to remove the head for otolith removal and the rest of the fish for genetic analysis. Each fish was given a unique identification number and the heads were stored in separate plastic bags in $95 \%$ ethanol. The body of each fish was placed in a separate plastic bag, immersed in liquid nitrogen, and subsequently transported back to the laboratory and stored at $-80{ }^{\circ} \mathrm{C}$ prior to molecular analysis. Ageing of smelt was validated by annual increment ageing on the otoliths of a subset of fish and thereafter body length was used (Crook et al. 2008). Body length over $50 \mathrm{~mm}$ total length (TL) was considered representative of smelt $1+$ years old.

\section{Otolith preparation and analysis}

The sagittal otoliths of 261 YOY fish and 141 1-year-old fish were dissected, cleaned of adhering tissue, triple-rinsed in Milli-Q water, and stored dry in polypropylene microtubes. One sagitta from each fish was then embedded whole, proximal surface facing downwards, on an acid-washed glass slide in a two-part epoxy resin (EpoFix ${ }^{\circledR}$, Struers AS, Ballerup, Denmark). Otoliths were polished to the level of the primordium using a series of wetted lapping films (particle diameter 9,5 , and $3 \mu \mathrm{m}$ ) followed by a final polish with alumina slurry $(0.5 \mu \mathrm{m})$. Up to 200 otoliths were mounted on each slide and arranged in random order to remove the potential for systematic measurement errors. After mounting, slides were allowed to dry and then were sonicated in Milli-Q water for 5 min and air-dried overnight in a plastic laminar flow cabinet.

Laser ablation inductively coupled plasma mass spectrometry (LA-ICPMS) was used to determine the elemental concentrations of the otoliths. For the 2004 samples, we used a Merchantek LUV $266 \mathrm{~nm}$ Nd:YAG UV laser microprobe (New Wave Research Inc., Fremont, California) operated in Q-switched mode and coupled to a Finnigan MAT ELEMENT high resolution ICPMS (Thermo Finnigan MAT $\mathrm{GmbH}$, Bremen, Germany) located at Monash University, Melbourne, Australia. Each otolith was ablated from the distal to the proximal surface using a $30 \mu \mathrm{m}$ diameter ablation spot (i) through the otolith edge at the widest radius of the dorsal margin and (ii) through the primordium. Data for edge and core signatures were selected from the first $15 \mathrm{~s}$ of the acquisition sequence for each otolith sample, which equated to $\sim 150$ laser scans. Based on examination of validated daily growth increments using similar methods to those described by Macdonald et al. (2008), we estimate that the data selected at the core incorporated the primordium and $<10$ days of otolith growth after hatch and that data selected at the otolith edge incorporated the last $\sim 15$ days of otolith growth prior to capture. Because of the limited dispersal opportunities available in the months preceding sampling in 2004, chemical signatures from the otolith edges (i.e., recent growth region) were considered to be representative of the environment at the collection sites. Otolith material sampled in the core regions was considered to represent the fish's natal chemical environment.

The laser was operated with output energy of $0.45-0.50$ $\mathrm{mJ}$ and a repetition rate of $6 \mathrm{~Hz}$. Ablation occurred inside a sealed chamber in an atmosphere of helium (flow rate, $0.36 \mathrm{~L} \cdot \mathrm{min}^{-1}$ ) with the ablated materials mixed with argon prior to transport to the ICPMS. Otoliths were analysed for several isotopes, including ${ }^{24} \mathrm{Mg},{ }^{43} \mathrm{Ca},{ }^{55} \mathrm{Mn},{ }^{88} \mathrm{Sr}$, and ${ }^{138} \mathrm{Ba} .{ }^{43} \mathrm{Ca}$ was measured for use as an internal standard to correct for variation in ablation yield among samples. The concentrations of the other isotopes were standardized to ${ }^{43} \mathrm{Ca}$ using the relative response of the instrument to known elemental concentrations in an external glass standard (National Institute of Standards Technology, NIST 612), and data were expressed as analyte to $\mathrm{Ca}$ molar ratios (i.e., $\mathrm{Mg}: \mathrm{Ca}, \mathrm{Mn}: \mathrm{Ca}, \mathrm{Sr}: \mathrm{Ca}, \mathrm{Ba}: \mathrm{Ca}$ ). The ablation chamber was purged for $20 \mathrm{~s}$ after each opening to remove any background gas or particles from previous samples. Mean counts of a $20 \mathrm{~s}$ background analysed prior to each ablation transect were subtracted from the averaged raw ion counts for each element over the interval of interest. The NIST 612 was analysed after every 10 samples to correct for any long-term drift in the instrument. Blank backgrounds, which measured the sample gases without ablation, were measured before each sampling session and used to determine detection limits. Detection limits (in $\mu \mathrm{g} \cdot \mathrm{g}^{-1}$ ) were calculated based on the ablation yield equivalent to $3 \times$ standard deviation $(\mathrm{SD})$ of the blank signal. Mean values for each element were as follows: $\mathrm{Mg}, 0.73$; $\mathrm{Mn}, 0.08 ; \mathrm{Sr}, 0.09$; and $\mathrm{Ba}, 0.01$. Precision of the method was calculated using the percentage of relative standard deviation (\%RSD) of mean concentrations of elements ablated from 150 laser scans of the NIST 612. Averaged values across all NIST 612 samples $(n=37)$ were as follows: $\mathrm{Mg}: \mathrm{Ca}, 3.1 \%$; $\mathrm{Mn}: \mathrm{Ca}, 4.2 \%$; $\mathrm{Sr}: \mathrm{Ca}, 2.4 \%$; and $\mathrm{Ba}: \mathrm{Ca}, 3.2 \%$.

In 2005, otolith chemistry analysis was conducted using a Resonetics LPX120i ArF 193 nm excimer laser system (Resonetics, Nashua, New Hampshire) coupled to an Agilent 7500s ICPMS (Agilent Technologies, Inc., Santa Clara, California) at the Australian National University (ANU). The uniform energy distribution and rapid response of this laser system allowed us to more precisely isolate data from the growth region of interest than the $266 \mathrm{~nm}$ laser system used to analyse the cores and edges of the 2004 samples (see Macdonald et al. 2008). We used a depth-profiling approach to sample a $70 \times 6 \mu \mathrm{m}$ target region at the otolith core that incorporated 2-10 days of otolith growth after hatch, but excluded material associated with the primordium (identified by a clear peak in Mn concentrations). The otolith core regions of the 141 1-year-old smelt collected in February 2005 were analysed in this way. To remove potential errors associated with interlaboratory comparisons (Campana et al. 1997), we also re-analysed the core regions of the second sagitta from 238 of the YOY smelt collected in February 2004 using the ANU system. The laser system was calibrated using NIST 610 and NIST 612 reference standards, and measurements of the concentrations of ${ }^{24} \mathrm{Mg},{ }^{43} \mathrm{Ca}$, ${ }^{55} \mathrm{Mn},{ }^{88} \mathrm{Sr}$, and ${ }^{138} \mathrm{Ba}$ were acquired for each otolith sample. Average detection limits $(3 \times \mathrm{SD}$ of the blank signal (in $\left.\mu \mathrm{g} \cdot \mathrm{g}^{-1}\right)$ ) for each element across all samples were as follows: $\mathrm{Mg}, 0.091 ; \mathrm{Mn}, 0.042$; Sr, 0.009; and $\mathrm{Ba}, 0.011$. Precision values (\%RSD) based on 22 means of a sequence of 39 laser scans (i.e., the same number of pulses used for otolith samples) on the NIST 612 were as follows: $\mathrm{Mg}: \mathrm{Ca}, 8.22 \%$; $\mathrm{Mn}: \mathrm{Ca}, 7.81 \%$; $\mathrm{Sr}: \mathrm{Ca}, 7.58 \%$; and $\mathrm{Ba}: \mathrm{Ca}, 10.35 \%$. Further information on the analytical procedures and laser operating parameters used can be found in Macdonald et al. (2008), 
and for a detailed description of the laser system's performance, see Eggins and Shelley (2002) and Eggins et al. (1998, 2005).

\section{Analysis of otolith chemistry data}

Spatial patterns in otolith edge and core chemistry for the 2004 samples were examined with univariate and multivariate ANOVAs and linear discriminant function analysis (DFA) using data from the Monash University system. Classification success for the DFAs was calculated by jackknifed cross-validation matrices, and standardized coefficients for the discriminant functions were used to measure which elements contributed most to site separation. We conducted randomization tests to determine if the jackknifed classification estimates were significantly different from random (see White and Ruttenberg 2007). Based on code provided by White and Ruttenberg (2007), a script was run in R (version 2.8.0, The R Foundation for Statistical Computing) to calculate the classification success rates and associated $P$ values (i.e., the probability of obtaining the observed classification rate due to chance alone) using uniform prior probabilities and 10000 randomizations of the data. All analyses were performed on $\log _{\mathrm{e}}$-transformed data.

Maximum likelihood estimation (MLE) was used to estimate the proportion of the 1-year-old fish captured in 2005 that had remained at their natal site since the previous summer. We used the 2004 YOY otolith core chemical signatures for each sampling site acquired using the ANU system $(n=238)$ as the baseline data set. Univariate and multivariate analyses of variance (ANOVAs) were conducted to ensure that the results were consistent between the Monash and ANU systems. Otolith chemistry data for the Broken River site was not considered suitable as baseline data because of the wide spread in the multi-elemental chemical signatures of fish from this site. Although exclusion of this site reduces the spatial extent of our analysis, our emphasis was to estimate the proportion of 1-year-old fish assigned as residents within each site, rather than attempting to describe all potential sources of fish. Thus, removal of the Broken River site does not affect the overall conclusions drawn from the otolith chemistry analysis. The MLEs were conducted for each catchment separately using the software program HISEA (Millar 1990), and we used the direct maximum likelihood estimator for all calculations. To investigate the variability of the estimator, 1000 simulations (with resampling) were run on the baseline data set (Campaspe, $n=59$; Goulburn, $n=99$; Ovens, $n=59$ ). Following the simulations, the software was run in analysis mode and the proportion of putative resident 1-year-old fish at each site was estimated.

\section{Allozymes}

Preparation of muscle tissue for allozyme electrophoresis followed methods in Hughes and Hillyer (2006). Initially, three individuals from each population were screened for polymorphism across 25 enzyme systems based on previously published protocols (Richardson et al. 1986). Five polymorphic loci (frequency of common allele < 0.99) were detected and genotyped for 30 individuals from each population using two standard individuals run on each plate. Locus names, abbreviations, and enzyme commission codes include glucose-6-phosphate isomerase ( $P G I, 5.3 .1 .9)$, aspartate transaminase (2 loci, $A A T-1$ and $A A T-2,2.6 .1 .1), \beta$ esterase $(\beta E S T, 3.1 .1 .1)$, and peptidase B (PEP-B, 3.4.1.1).

\section{Microsatellites}

Total genomic DNA was extracted from muscle tissue following a cetyltrimethyl ammonium bromide (CTAB) phenol - chloroform extraction protocol (Doyle and Doyle 1987). The 30 individuals used for allozyme analysis from each population were genotyped for four polymorphic microsatellite loci (Sm18, Sm26, Sm49, and Sm80) (Hillyer et al. 2006). PCR reactions and product preparation for electrophoresis followed the methods described by Hillyer et al. (2006). Individuals were genotyped at each locus using a $5 \%$ denaturing acrylamide gel on a Gel-Scan 2000 DNA analyser (Corbett Research, Sydney, Australia). Allele size was determined against a Genemark 350-TAMRA size marker (Astral Scientific, Gymea, NSW, Australia) along with two internal PCR standards on each gel. Alleles were visualized and scored using ONE-DSCAN software (Scanalytics Inc., Fairfax, Virginia).

\section{Mitochondrial DNA}

A region of the mtDNA genome spanning ATPase 6 and ATPase 8 was amplified according to the polymerase chain reaction (PCR) protocol of McGlashan and Hughes (2000). Amplified product from five individuals was sequenced in both directions, and a new reverse primer was developed and used in further amplifications, smelt r-7 (5'-AGCCGTAGGTTGGTTGGTTTCGCAT-3'). Amplified product was purified via an enzymatic purification protocol using exonuclease I (Fermentas International Inc., Burlington, Ontario, Canada) and shrimp alkaline phosphatase (Promega Corporation, Madison, Wisconsin) and sequenced on an $\mathrm{ABI}$ 3130xl (Applied Biosystems, Life Technologies Corporation, Carlsbad, California) automated sequencer at the Griffith University DNA Sequencing Facility. Twenty individuals were sequenced from each population; these were randomly selected from the 30 individuals used in allozyme and microsatellite analysis. Haplotype sequences were lodged with GenBank under accession nos. FJ593511 to FJ593561 (Appendix A, Table A1).

\section{Intrapopulation diversity}

Tests for linkage disequilibrium and departures in genotypic proportions expected from Hardy-Weinberg equilibrium (HWE) were calculated with exact tests for each locus-population combination using default settings in GENEPOP (Raymond and Rousset 1995). Population-level diversity was estimated for allozyme and microsatellite markers using expected heterozygosity and allelic richness in GENEPOP. Mitochondrial sequences were edited and aligned using BIOEDIT (Hall 1999). Genetic variation within populations was assessed using haplotype diversity (h) in ARLEQUIN (version 3.1; Excoffier et al. 2005). Nucleotide variation across the study area was used to test for historical changes in the demography of smelt in the upper Murray-Darling Basin. Dramatic changes to population size (e.g., bottlenecks and population expansions) may alter both haplotype diversity and variation in segregating sites relative to the patterns expected for stable populations (Ramos- 
Onsins and Rozas 2002). Fu's $F_{S}$ statistic (Fu 1997) was used to test for a signature of population expansion that manifests in an excess of haplotypes relative to expectations for a historically stable population. The $R_{2}$ statistic (Ramos-Onsins and Rozas 2002) was used to test for an excess of singleton substitutions (i.e., base changes sampled only once), which are likewise characteristic of rapidly expanding populations. In addition, a mismatch distribution of pairwise base differences among all individuals was calculated for comparison with the distribution expected for an exponentially growing population. An estimate of the time of the expansion was taken using the expectation $\tau=2 u t$ (Rogers 1995), where $\tau$ is the age of the expansion in mutational units derived from the mismatch distribution, $u$ is the per-generation nucleotide substitution rate for the gene fragment based on a yearly pernucleotide substitution rate of $0.65 \times 10^{-8}$ (Bermingham et al. 1997) and average generation time of one year (Pusey et al. 2004), and $t$ is the unknown expansion time in generations. Fu's $F_{S}$, the mismatch distribution, and $R_{2}$ were calculated in DnaSP (version 4.50; Rozas et al. 2003).

\section{Population genetic structure and individual assignment}

Pairwise comparisons of genetic structure were calculated for each genetic marker using $F_{\mathrm{ST}}$ estimates in ARLEQUIN (version 3.1; Excoffier et al. 2005). The critical value $(\alpha)$ was corrected for multiple tests using the BY false discovery rate method (BY-FDR), which controls experiment-wide type I error without the loss of power to detect differentiated populations, that is associated with the Bonferroni adjustment (Benjamini and Yekutieli 2001; Narum 2006). Mantel tests (Mantel 1967) were used to test for isolation-bydistance (IBD) where Slatkin's linearized $F_{\mathrm{ST}}$ (Slatkin 1995) was used as a measure of genetic differentiation, and river distances (Fetzner and Crandall 2003) were measured from a topographic map with a scale of $1: 250000$. Tests for IBD were conducted across all sample sites separately for mtDNA, microsatellites, and allozymes markers.

The influence of hierarchical river structure on spatial genetic variation was tested with analysis of molecular variance (AMOVA) in ARLEQUIN (version 3.1; Excoffier et al. 2005) for each genetic marker. The hierarchical levels of analysis and their associated $F$ statistics include among catchments $\left(F_{\mathrm{CT}}\right)$, among sites within catchments $\left(F_{\mathrm{SC}}\right)$, and among all sites $\left(F_{\mathrm{ST}}\right)$. Sequence divergence was incorporated into the AMOVA for the mtDNA data by calculating $\Phi_{\mathrm{ST}}$ based on uncorrected pairwise differences between haplotypes.

Individuals were classified as either residents or first-generation $\left(\mathrm{F}_{0}\right)$ immigrants to populations represented by 30 individuals collected at each sampling location in 2004, using individual assignment and population exclusion methods implemented in GENECLASS (version 2; Piry et al. 2004). Individual assignment probabilities were calculated using the partial Bayesian approach of Rannala and Mountain (1997) using four microsatellite loci. The test statistic used for classification of each individual as resident or immigrant was the likelihood of drawing the individual's genotype from its population of origin $\left(L_{\mathrm{h}}\right)$, which is appropriate to the present situation in which all potential source populations are not sampled (Paetkau et al. 2004). The simulation algorithm of
Paetkau et al. (2004) was used to generate 10000 resident genotypes and derive an associated distribution of assignment probabilities for each location. Individuals were excluded as residents and classed as immigrants when $L_{\mathrm{h}}$ fell within the 0.01 tail of this distribution (Paetkau et al. 2004). Re-establishment of hydrological connectivity during spring and winter 2004 allowed us to examine whether the potential for dispersal had a detectable impact on individual assignment rates for smelt collected in 2005. Eleven sites were successfully resampled in 2005, and approximately 20 individuals from each site were assigned to reference data collected from the same location in 2004 before hydrological connection occurred.

\section{Results}

\section{Spatial variation in otolith chemical signatures}

Substantial differences in the concentrations of $\mathrm{Mn}: \mathrm{Ca}$, $\mathrm{Sr}: \mathrm{Ca}$, and $\mathrm{Ba}: \mathrm{Ca}$ in otolith edges were observed both among and within catchments, yet $\mathrm{Mg}: \mathrm{Ca}$ concentrations were relatively similar across all sites based on data from the Monash laser system (Table 1a; Fig. 2). The results of the multivariate ANOVAs and linear DFAs showed that it was possible to discriminate between most sampling sites within catchments using the multi-elemental signatures of the otolith edges (Table $1 b$; Fig. 3). There was substantial overlap in the otolith edge chemical signatures of fish from the different catchments, resulting in only moderate classification accuracy across catchments $(61 \%, P<0.001)$ (Table 2). However, sites within catchments tended to be more distinct, with overall classification success rates of 67\% $(P=0.032)$ in the Campaspe, $83 \%(<0.001)$ in the Goulburn, and $97 \%(P<0.001)$ in the Ovens catchments. The lower classification success among the Campaspe sites was mainly due to the similarity in otolith edge signatures between Forest Creek and McIvor Creek smelt (Table 2; Fig. 2). Examination of the standardized coefficients showed that $\mathrm{Mn}: \mathrm{Ca}$ was most influential in the discriminant functions at the catchment scale but had little influence at the site scale. $\mathrm{Sr}: \mathrm{Ca}$ and, to a lesser extent, $\mathrm{Ba}: \mathrm{Ca}$ were responsible for much of the observed variation in otolith edge chemistry among sites (Table 3).

Similar to the otolith edges, the analysis of core otolith chemistry revealed significant univariate and multivariate differences in elemental concentrations among catchments and among sites within catchments, with comparable results obtained using both the Monash and ANU laser systems (Table 1; Figs. 2, 3). Because of the lack of hydrological connectivity at most sites prior to sampling, YOY smelt collected in February 2004 are likely to have been restricted to their natal site since they were spawned. Hence, we would expect relatively high classification success of individuals based on otolith core chemistry. The linear DFAs based on data from the Monash system confirm this and show clear discrimination among most sampling sites within catchments, with classification accuracy similar to and, in many cases, higher than those of the otolith edges (Table 2; Fig. 3). Ba:Ca and Mn:Ca were most influential in the discriminant analysis at the catchment scale. At the site scale, $\mathrm{Sr}: \mathrm{Ca}$ and $\mathrm{Ba}: \mathrm{Ca}$ were most important, whereas Mn:Ca had relatively little influence (Table 3 ). 
Table 1. (a) Mean squares (MS) and significance levels for a two-way nested analysis of variance (ANOVA) on mean $\log _{\mathrm{e}^{-}}$ transformed $\mathrm{Mg}: \mathrm{Ca}, \mathrm{Mn}: \mathrm{Ca}, \mathrm{Sr}: \mathrm{Ca}$, and $\mathrm{Ba}: \mathrm{Ca}$ in the edge and core regions of young-of-year (YOY) Australian smelt otoliths ( $n=261$ ) analysed on the Merchantek LUV $266 \mathrm{~nm}$ laser at Monash University (Monash) and in the core region of the second otolith from 238 of these fish analysed on the Resonetics $193 \mathrm{~nm}$ laser at the Australian National University (ANU). (b) Results from one-way multivariate ANOVAs on $\log _{\mathrm{e}}$-transformed $\mathrm{Mg}: \mathrm{Ca}, \mathrm{Mn}: \mathrm{Ca}, \mathrm{Sr}: \mathrm{Ca}$, and $\mathrm{Ba}: \mathrm{Ca}$ in the edge and core regions of YOY Australian smelt otoliths analysed at Monash University $(n=261)$ and in the core region of the second otolith from 238 of these fish analysed at the ANU. Comparisons are made among the three river catchments (Campaspe, Goulburn, Ovens) and among sites within catchments.

\begin{tabular}{|c|c|c|c|c|c|c|c|c|c|}
\hline \multirow[b]{2}{*}{ Source } & \multirow[b]{2}{*}{ df } & \multicolumn{2}{|c|}{ MS Mg:Ca } & \multicolumn{2}{|l|}{ MS Mn:Ca } & \multicolumn{2}{|l|}{ MS Sr:Ca } & \multicolumn{2}{|l|}{ MS Ba:Ca } \\
\hline & & Edge & Core & Edge & Core & Edge & Core & Edge & Core \\
\hline \multicolumn{10}{|l|}{ Monash } \\
\hline Catchment & 2 & 0.165 & 0.154 & $14.087 * * *$ & $13.581 * * *$ & $0.749 * * *$ & $0.608 * * *$ & $9.172 * * *$ & $11.489 * * *$ \\
\hline Site (catchment) & 9 & 0.272 & 0.243 & $3.831 * * *$ & $2.326 * * *$ & $1.675^{* * *}$ & $1.907 * * *$ & $5.956 * * *$ & $2.815 * * *$ \\
\hline Error & 249 & 0.231 & 0.177 & 0.238 & 0.313 & 0.020 & 0.016 & 0.077 & 0.053 \\
\hline \multicolumn{10}{|l|}{ ANU } \\
\hline Catchment & 2 & & 0.002 & & $7.595 * * *$ & & $0.297 * * *$ & & $10.882 * * *$ \\
\hline Site (catchment) & 9 & & $0.027 *$ & & $1.089 * * *$ & & $1.227 * * *$ & & $1.447 * * *$ \\
\hline Error & 226 & & 0.010 & & 0.299 & & 0.015 & & 0.064 \\
\hline
\end{tabular}

(b) Results from one-way multivariate ANOVAs

\begin{tabular}{|c|c|c|c|c|c|}
\hline \multirow[b]{2}{*}{ Source } & \multirow[b]{2}{*}{ Source, error df } & \multicolumn{2}{|c|}{ Pillai's trace } & \multicolumn{2}{|l|}{$F$} \\
\hline & & Edge & Core & Edge & Core \\
\hline \multicolumn{6}{|l|}{ Monash } \\
\hline Catchment & 8,512 & 0.375 & 0.520 & $14.757 * * *$ & $24.286 * * *$ \\
\hline Sites (Campaspe) & 8,124 & 0.489 & 0.780 & $5.022 * * *$ & $10.071 * * *$ \\
\hline Sites (Goulburn) & 20,492 & 2.063 & 1.766 & $26.213 * * *$ & $19.442 * * *$ \\
\hline Sites (Ovens) & 8,120 & 1.714 & 1.564 & $89.792 * * *$ & $53.831 * * *$ \\
\hline \multicolumn{6}{|l|}{ ANU } \\
\hline Catchment & 8,446 & & 0.602 & & $25.104 * * *$ \\
\hline Sites (Campaspe) & 8,108 & & 0.842 & & $9.809 * * *$ \\
\hline Sites (Goulburn) & 20,456 & & 1.489 & & $13.517 * * *$ \\
\hline Sites (Ovens) & 8,108 & & 1.253 & & $22.648 * * *$ \\
\hline
\end{tabular}

Note: The 12 sampling sites from which YOY fish were collected are nested within the three river catchments (Campaspe, Goulburn, Ovens). df, degrees of freedom; *, $P<0.05$; **, $P<0.01$; ***, $P<0.001$.

\section{Dispersal estimation using otolith core chemistry}

Estimates of the proportions of 1-year-old fish classified as residents or immigrants were undertaken using the otolith core chemistry data acquired with the ANU system. We were unable to collect any 1-year-old fish at several sites, whereas at others (e.g., Croppers Creek, Hurdle Creek), interpretation was limited by low sample sizes (Table 4). In the Campaspe catchment, 95\% $(n=21)$ of 1-year-old smelt collected from McIvor Creek were assigned to their site of collection (i.e., putative residents) based on their otolith core chemistry, and all 27 fish collected from the Campaspe River were classified as residents (Table $4 a$ ). By contrast, estimates for the Goulburn catchment suggested that at most sites, a high proportion of 1-year-old fish were nonresidents that had migrated into the sampling site since February 2004. Of the 55 1-year-old smelt analysed, only $16 \%$ were classified as residents based on their otolith core chemistry. None of the fish collected at Castle Creek $(n=9)$ or Seven Creeks $(n=10)$ was assigned to their collection sites, and $47 \%(n=23)$ of fish collected from Reedy Lake Creek were classified as residents (Table $4 b$ ). In the Ovens catchment, it was estimated that $94 \%(n=17)$ of 1 -year-old smelt captured at Reedy Creek were residents (Table $4 c$ ). The low numbers of 1-year-old smelt captured at Croppers Creek and Hurdle Creek limits interpretation for these sites, although $88 \%(n=8)$ of fish collected from Hurdle Creek and Croppers Creek were classified as nonresidents.

\section{Intrapopulation genetic diversity}

Genetic diversity was higher for microsatellite loci than for allozymes in all populations, with microsatellite allelic richness and heterozygosity ranging from 6.25 to 11.25 and from $51 \%$ to $80 \%$, respectively, compared with the lower allozyme values ranging from 2.0 to 3.0 and from $20 \%$ to $42 \%$ (Table 5). Tests for HWE and linkage disequilibrium indicate no evidence for systematic deviations from random assortment at any locus in both 2004 and 2005 samples. A 502 bp alignment of ATPase from 260 individuals (20 individuals/population) included 46 variable positions and 51 unique haplotypes. Moderately high haplotype diversity was observed in all populations, with the number of haplotypes sampled in each population ranging from 4 to 13 (Table 5; Appendix A, Table A1). 
Fig. 2. Mean (+ standard error, SE) concentrations of (a) $\mathrm{Mg}: \mathrm{Ca}$, (b) $\mathrm{Mn}: \mathrm{Ca}$, (c) Sr:Ca, and (d) Ba:Ca in the edge (open bars) and core (solid bars) regions of Australian smelt (Retropinna semoni) otoliths collected from 12 sites in the Campaspe, Goulburn, and Ovens River catchments. Otolith analyses were conducted on the Merchantek LUV $266 \mathrm{~nm}$ laser system operated at Monash University. Sites: CR, Campaspe River; FC, Forest Creek; MC, McIvor Creek; SE, Seven Creeks; CA, Castle Creek; SC, Sugarloaf Creek; DC, Dabyminga Creek; RL, Reedy Lake Creek; BR, Broken River; RC, Reedy Creek; CC, Castle Creek; HC, Hurdle Creek.
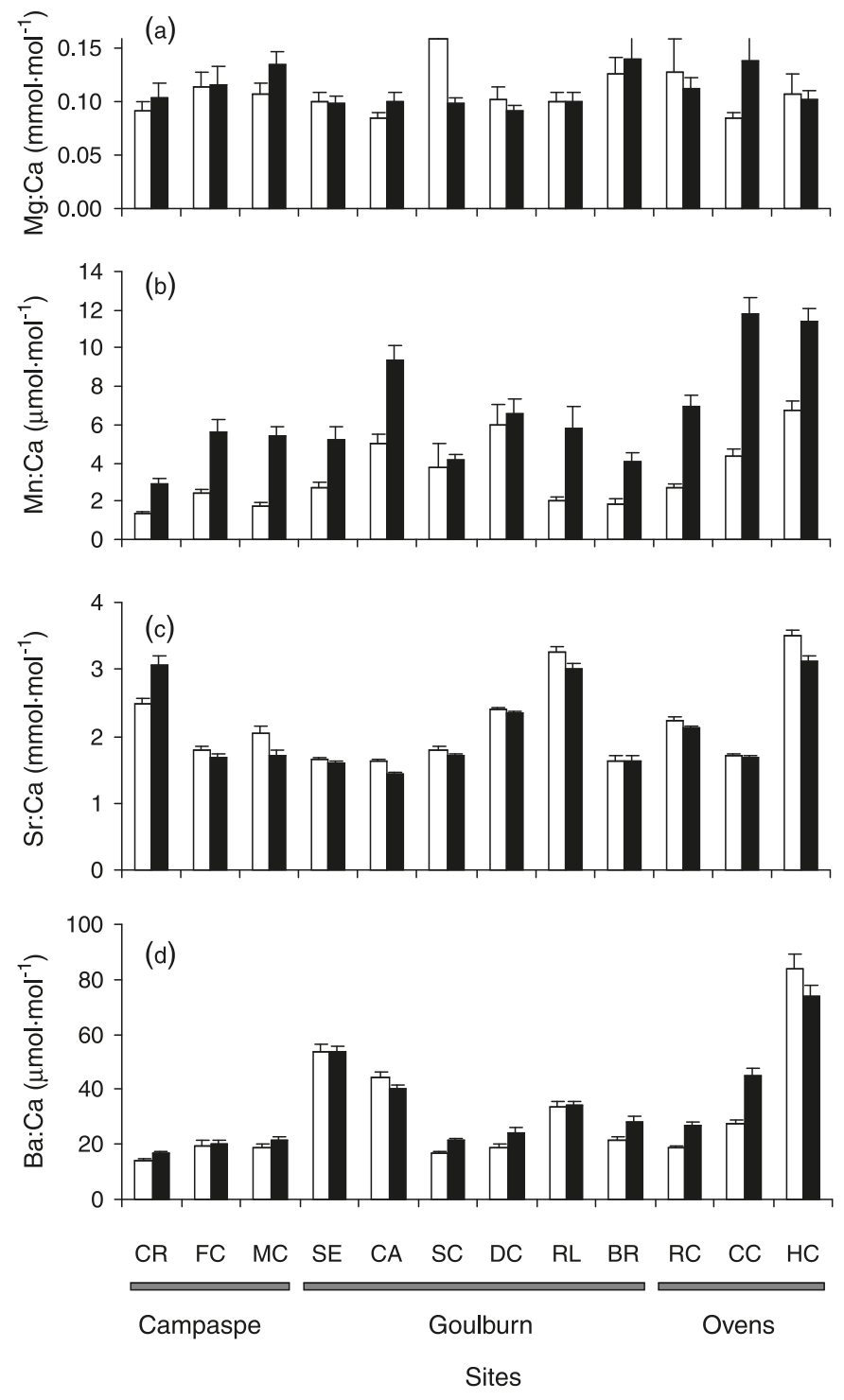

Statistical tests for population growth based on the mtDNA locus were consistent with a historical population expansion event. The observed Fu's $F_{S}$ value of $-56.5(P<$ 0.001 ) is consistent with an excess of haplotypes relative to expectations for a stable population. The small $R_{2}$ value of $0.022(P<0.001)$ reflects an excess of singleton substitutions in the mtDNA data set, which is consistent with a historical growth event. The shape of the mismatch distribution is unimodal, smooth, and left-skewed as expected for a population that has undergone a historically recent expansion. Assuming that population growth is responsible for this pat- tern of variation, then the timing of the expansion event ( $\tau=$ 1.788 ) is on the order of 275000 years.

\section{Spatial structuring of genetic variation}

Structuring of genetic variation was nonrandom across populations for mtDNA $\left(\Phi_{\mathrm{ST}}=0.213\right)$, allozymes $\left(F_{\mathrm{ST}}=\right.$ $0.095)$, and microsatellites $\left(F_{\mathrm{ST}}=0.045\right)$, indicating that smelt are not panmictic in the study area (Table 6). Pairwise comparisons indicated that a large proportion of populations were significantly differentiated from each other. The BY-FDR corrected critical value of $P \leq 0.00987$ was used for 78 pairwise comparisons and $40(51 \%)$ tests were significant for mtDNA, whereas $60(77 \%)$ and $51(65 \%)$ tests were significant for microsatellites and allozymes, respectively. Hierarchical structuring of the river network in accordance with the SHM was a poor predictor of genetic structure. Partitioning of variation among the catchments $\left(F_{\mathrm{CT}}\right)$ is expected to be relatively high according to the SHM, but we found the reverse, with catchments accounting for less than $0.3 \%$ of variation in a hierarchical AMOVA and the corresponding $F_{\mathrm{CT}}$ values are low and nonsignificant (Table 6). This result was consistent across each of the three genetic marker types used and for most loci except Sml8 and PGI (Table 6). Current barriers to movement in the regulated rivers do not appear to explain the observed pattern of genetic structuring. For example, significant structuring in the Campaspe catchment is attributable to differentiation between upper (McIvor Creek) and lower (Forest Creek, Campaspe River) populations rather than between the two latter populations, which are separated by the Campaspe Weir.

Tests for isolation by river distance across the study area were nonsignificant for each of the three genetic markers (mtDNA, $r=-0.106, P=0.6$ (Fig. 4a); allozymes, $r=$ $-0.067, P=0.64$ (Fig. 4b); microsatellites, $r=-0.179$, $P=0.8$ (Fig. $4 c$ )). Three populations are responsible for a disproportionate number of high $F_{\mathrm{ST}}$ values in the IBD scatterplots (Fig. 4). For the mtDNA data, all 19 pairwise comparisons with $F_{\mathrm{ST}}>0.3$ involve Sugarloaf Creek and Dabyminga Creek samples. These two populations, along with McIvor Creek, are responsible for 20 of the 24 pairwise $F_{\mathrm{ST}}>0.06$ for the microsatellite data. For the allozyme data set, McIvor Creek alone accounts for 10 of the 14 comparisons of $F_{\mathrm{ST}}>0.15$.

\section{Dispersal estimation using genetics: classification of resident-immigrant status}

The null hypothesis of resident status for fish collected in 2004 was rejected for 13 out of a total of 390 individuals (3.3\%) from 13 locations throughout the study area. In any given population, $\geq 93 \%$ of individuals fell within the expected distribution of assignment scores for resident genotypes (Table 4). Immigrant genotypes were distributed across nine populations, including all catchments. Exclusion tests for each of the 13 putative immigrants against all populations in the same catchment revealed that five "immigrants" were excluded as residents from all sampled populations and the remaining eight "immigrants" could not be excluded as residents from multiple populations. It therefore appears likely that some of the genetically identified immigrants represent true $\mathrm{F}_{0}$ immigrants whose source 
Fig. 3. Discriminant function plots displaying spatial variation in multi-elemental signatures (Mg:Ca, $\mathrm{Mn}: \mathrm{Ca}, \mathrm{Sr}: \mathrm{Ca}, \mathrm{Ba}: \mathrm{Ca})$ of edge and core regions of young-of-year (YOY) Australian smelt (Retropinna semoni) otoliths collected in February 2004: (a) among catchments and among sites within $(b)$ the Campaspe, $(c)$, the Goulburn and $(d)$ the Ovens catchments. Ellipses represent $95 \%$ confidence intervals around the group centroid. Data points represent multi-elemental otolith signatures for individual smelt, and plots are based on loge-transformed data from the Monash University laser system.
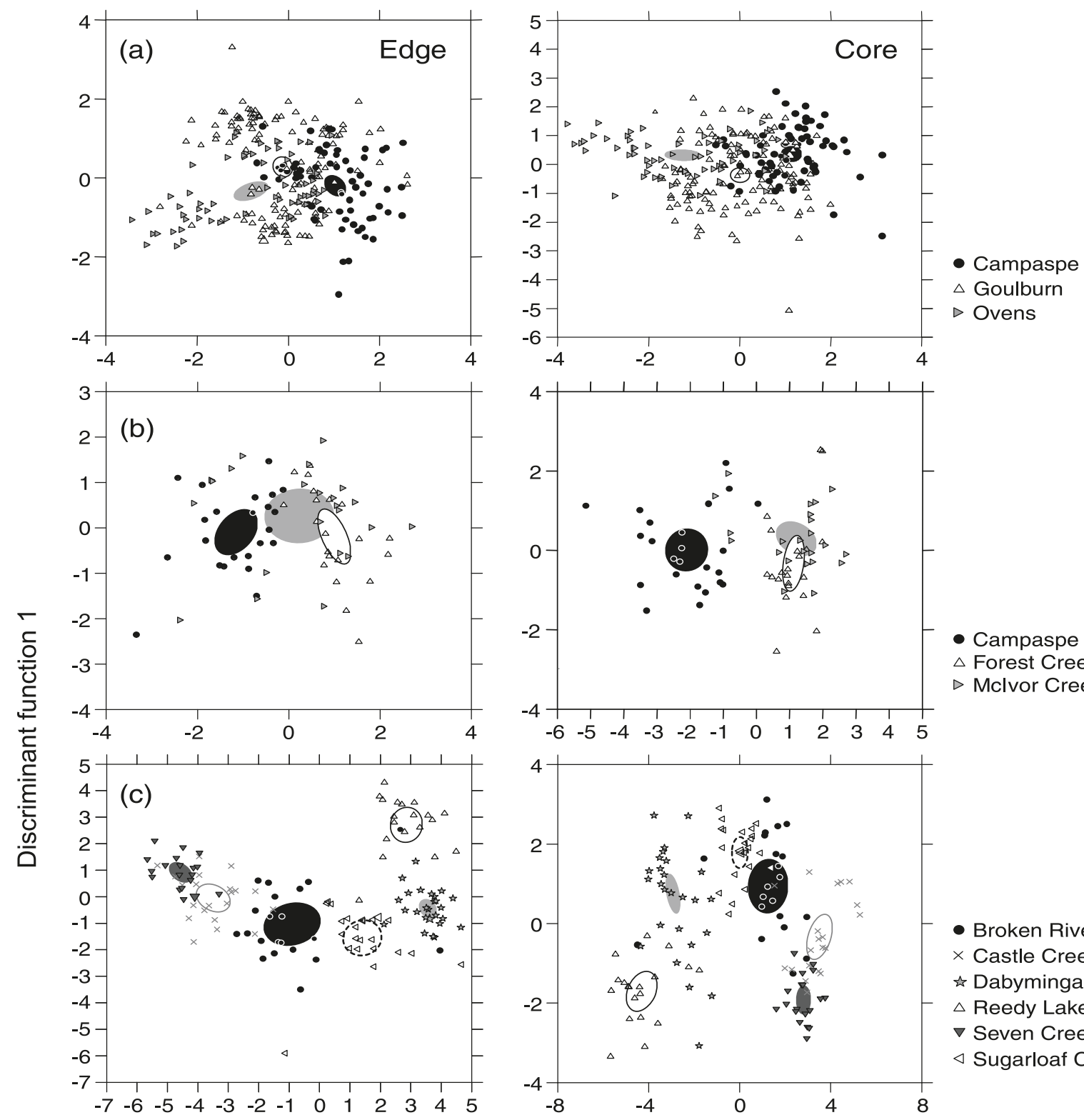

- Campaspe River

$\triangle$ Forest Creek

$\triangleright$ Mclvor Creek

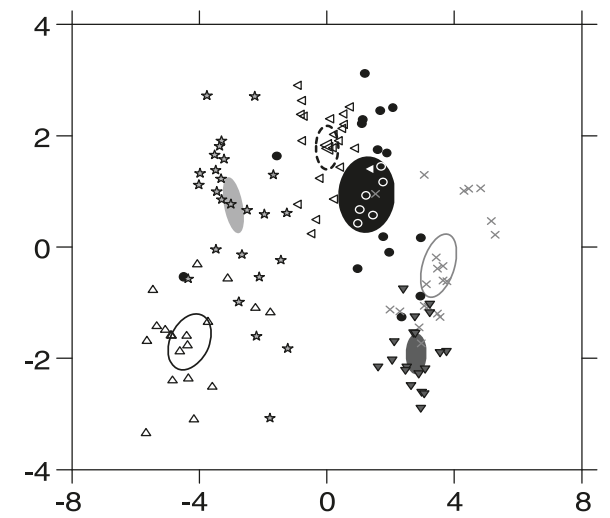

- Broken River

$\times$ Castle Creek

is Dabyminga Creek

$\triangle$ Reedy Lake Creek

$\nabla$ Seven Creeks

$\triangleleft$ Sugarloaf Creek
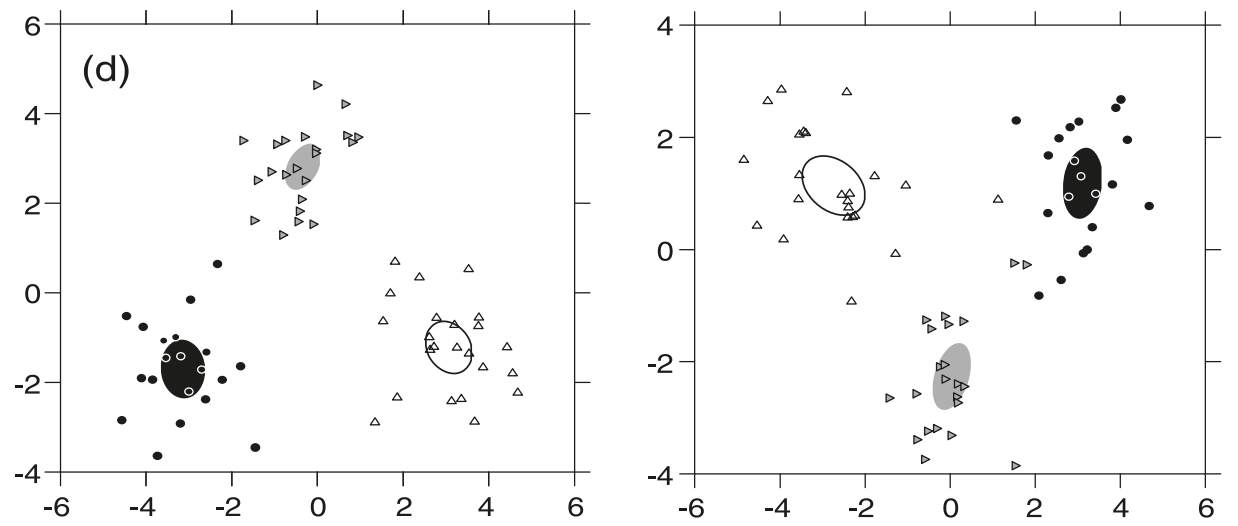

- Croppers Creek

$\triangle$ Hurdle Creek

$\triangleright$ Reedy Creek

\section{Discriminant function 2}


Table 2. Success of classifying individual young-of-year (YOY) Australian smelt collected in February 2004 to their collection site based on the otolith chemistry of the edge and core regions $(a)$ among catchments and within $(b)$ the Campaspe catchment, $(c)$ the Goulburn catchment, and $(d)$ the Ovens catchment.

\begin{tabular}{|c|c|c|c|c|c|}
\hline & \multirow[b]{2}{*}{$n$} & \multicolumn{2}{|c|}{ Otolith edge } & \multicolumn{2}{|c|}{ Otolith core } \\
\hline & & $\%$ correct & $P$ & $\%$ correct & $P$ \\
\hline \multicolumn{6}{|c|}{ (a) Among catchments } \\
\hline Campaspe & 67 & 75 & & 78 & \\
\hline Goulburn & 129 & 58 & & 54 & \\
\hline Ovens & 65 & 54 & & 72 & \\
\hline Total & 261 & 61 & $<0.001$ & 65 & $<0.001$ \\
\hline \multicolumn{6}{|c|}{ (b) Within the Campaspe catchment } \\
\hline Campaspe River & 23 & 83 & & 91 & \\
\hline Forest Creek & 21 & 86 & & 71 & \\
\hline McIvor Creek & 23 & 35 & & 57 & \\
\hline Total & 67 & 67 & 0.032 & 73 & $<0.001$ \\
\hline \multicolumn{6}{|c|}{ (c) Within the Goulburn catchment } \\
\hline Broken River & 21 & 81 & & 67 & \\
\hline Castle Creek & 21 & 71 & & 86 & \\
\hline Dabyminga Creek & 26 & 88 & & 92 & \\
\hline Reedy Lake Creek & 19 & 95 & & 95 & \\
\hline Seven Creeks & 19 & 84 & & 84 & \\
\hline Sugarloaf Creek & 23 & 78 & & 96 & \\
\hline Total & 129 & 83 & $<0.001$ & 87 & $<0.001$ \\
\hline \multicolumn{6}{|c|}{ (d) Within the Ovens catchment } \\
\hline Croppers Creek & 20 & 90 & & 100 & \\
\hline Hurdle Creek & 23 & 100 & & 96 & \\
\hline Reedy Creek & 22 & 100 & & 95 & \\
\hline Total & 65 & 97 & $<0.001$ & 97 & $<0.001$ \\
\hline
\end{tabular}

Table 3. Standardised coefficients and percent dispersion explained for the first two discriminant functions (DF1, $\mathrm{DF} 2)$ in analyses of intercatchment and within-catchment otolith $(a)$ edge and $(b)$ core chemical signatures of young-of-year (YOY) Australian smelt collected in February 2004.

\begin{tabular}{|c|c|c|c|c|c|c|c|c|}
\hline & \multicolumn{2}{|c|}{ Intercatchment } & \multicolumn{2}{|c|}{ Campaspe } & \multicolumn{2}{|c|}{ Goulburn } & \multicolumn{2}{|l|}{ Ovens } \\
\hline & DF1 & DF2 & DF1 & DF2 & DF1 & DF2 & DF1 & DF2 \\
\hline \multicolumn{9}{|l|}{ (a) Edge } \\
\hline $\mathrm{Mg}: \mathrm{Ca}$ & 0.210 & 0.022 & 0.156 & 0.346 & 0.054 & 0.331 & 0.115 & 0.362 \\
\hline $\mathrm{Mn}: \mathrm{Ca}$ & -0.668 & 0.061 & 0.297 & -0.927 & 0.351 & -0.324 & 0.143 & -0.162 \\
\hline $\mathrm{Sr}: \mathrm{Ca}$ & -0.114 & 1.057 & -0.802 & -0.063 & 1.145 & 0.576 & 1.135 & 0.879 \\
\hline $\mathrm{Ba}: \mathrm{Ca}$ & -0.471 & -0.555 & 0.395 & 0.752 & -1.146 & 0.603 & -0.230 & -1.364 \\
\hline Dispersion (\%) & 78.4 & 21.6 & 95.4 & 4.6 & 76.9 & 15.4 & 68.1 & 31.9 \\
\hline \multicolumn{9}{|l|}{ (b) Core } \\
\hline $\mathrm{Mg}: \mathrm{Ca}$ & 0.003 & 0.175 & 0.160 & 0.935 & 0.176 & 0.189 & 0.160 & 0.361 \\
\hline $\mathrm{Mn}: \mathrm{Ca}$ & -0.443 & 0.623 & 0.158 & -0.163 & 0.147 & 0.004 & 0.227 & 0.187 \\
\hline $\mathrm{Sr}: \mathrm{Ca}$ & -0.174 & 0.776 & -0.918 & 0.227 & -1.026 & -0.286 & -1.107 & -0.387 \\
\hline $\mathrm{Ba}: \mathrm{Ca}$ & -0.768 & -0.565 & 0.329 & 0.497 & 0.511 & -0.899 & 0.191 & 1.144 \\
\hline Dispersion (\%) & 84.7 & 15.3 & 97.4 & 2.6 & 78.9 & 18 & 68.2 & 31.8 \\
\hline
\end{tabular}

Note: Analyses were based on data from the Monash University laser system.

population was not sampled in the present study, whereas others may represent type I errors (true residents that are incorrectly rejected within the tolerated threshold of $\alpha=0.01$ used for these tests). Eleven sites were resampled in 2005 after hydrological connection occurred during spring and winter 2004. The null hypothesis that each individual collected in 2005 belonged to the population of genotypes sampled from the same location in 2004 was rejected for 12 
Table 4. Assignment tests of resident status for individuals in each population based on multilocus genetic data for 2003 and 2004 cohorts (Genetics 2004) and 2004 and 2005 cohorts (Genetics 2005).

\begin{tabular}{|c|c|c|c|c|c|c|}
\hline \multirow[b]{2}{*}{ Site } & \multicolumn{2}{|c|}{ Genetics 2004} & \multicolumn{2}{|c|}{ Genetics 2005} & \multicolumn{2}{|c|}{ Otolith chemistry } \\
\hline & $n$ & $\%$ resident & $n$ & $\%$ resident & $n$ & $\%$ resident \\
\hline \multicolumn{7}{|c|}{ (a) Campaspe catchment } \\
\hline Campaspe River & 30 & 93 & 20 & 95 & 27 & 100 \\
\hline Forest Creek & 30 & 100 & 0 & - & 0 & - \\
\hline McIvor Creek & 30 & 97 & 20 & 100 & 21 & 93 \\
\hline Total or average & 90 & 97 & 40 & 98 & 48 & 97 \\
\hline \multicolumn{7}{|c|}{ (b) Goulburn catchment } \\
\hline Broken River & 30 & 100 & 20 & 100 & 0 & - \\
\hline Castle Creek & 30 & 93 & 19 & 100 & 9 & 0 \\
\hline Dabyminga Creek & 30 & 97 & 20 & 90 & 0 & - \\
\hline Reedy Lake Creek & 30 & 93 & 20 & 100 & 23 & 47 \\
\hline Seven Creeks & 30 & 97 & 20 & 75 & 10 & 0 \\
\hline Sugarloaf Creek & 30 & 97 & 20 & 95 & 13 & 17 \\
\hline Glen Creek & 30 & 100 & 0 & - & 0 & - \\
\hline Total or average & 210 & 97 & 119 & 93 & 68 & 16 \\
\hline \multicolumn{7}{|c|}{ (c) Ovens catchment } \\
\hline Croppers Creek & 30 & 97 & 20 & 100 & 2 & 50 \\
\hline Hurdle Creek & 30 & 100 & 20 & 85 & 6 & 0 \\
\hline Reedy Creek & 30 & 93 & 20 & 100 & 17 & 94 \\
\hline Total or average & 90 & 97 & 60 & 95 & 25 & 72 \\
\hline
\end{tabular}

Note: Maximum likelihood estimation (MLE) using otolith core chemistry data for the 2004 cohort collected as 1-year-olds in February 2005 (otolith chemistry). Otolith analyses were conducted separately for each of the three catchments ( $(a)$ Campaspe, $(b)$ Goulburn, and (c) Ovens) and were based on data from the ANU laser system. Assignments using otolith chemistry methods were conducted on 1-year-old fish, and genetic assignments included young-of-year (YOY) and 1-year-old fish. Total or average: total $n$ values, average $\%$ resident.

out of a total of 219 individuals $(5.5 \%)$. The proportion of individuals from each 2005 site that fell within the expected distribution of assignment scores for 2004 ranged from $75 \%$ to $100 \%$ (Table 4 ).

\section{Discussion}

\section{Contemporary dispersal}

Analysis of the otolith chemistry and genetic data provide important insights into the within-lifetime dispersal histories of Australian smelt. Analysis of the genetic data from the 2004 samples, which included both YOY (2004 cohort) and 1-year-old fish (2003 cohort), showed that the most pronounced structuring of variation in all markers occurred between relatively closely spaced populations within catchments. Most relevant to contemporary dispersal patterns, the assignment tests based on microsatellite variation provide information on whether the genetic composition of an individual is the result of random mating within a population of resident parental genes or if it is an immigrant whose genetic makeup is derived from a different population of parental genes. The low number $(<4 \%)$ of immigrants detected using these tests provides evidence that the genetic variation recovered from each sampling location is representative of the existence of a series of stationary local populations and suggests very limited dispersal by the 2003 and 2004 cohorts prior to their collection in summer 2004.

Analysis of the otolith chemistry data for the YOY fish collected in summer 2004 (2004 cohort) yields a similar in- terpretation, indicating that genetics and otoliths yield complimentary information on population structure of smelt. Given the distinctive otolith chemical signatures of YOY fish observed among sites within catchments, as evidenced by the analysis of otolith edge chemistry, disparate natal (core) chemical signatures would have been expected among fish from particular sites if recruits had dispersed throughout or among catchments from one or more common spawning grounds. However, the tightly grouped and spatially distinct natal chemical signatures of fish from the vast majority of sites (the Broken River was an exception) strongly suggest that most new recruits were retained in localized areas within catchments after spawning. An alternative explanation for this pattern is that recruits dispersed throughout or among catchments in nonmixing groups with distinctive core chemistry signatures that were not reflective of the sites from which the fish were sampled. The likelihood that such an explanation has a significant effect on the interpretation of our results appears remote, however, considering the similarity in spatial patterns between the core and edge chemical signatures and the lack of hydrological connectivity prior to sampling. In the more ephemeral streams (e.g., McIvor Creek, Forest Creek, Castle Creek), the finding of limited dispersal by the 2004 cohort is not surprising because dispersal of juvenile fish away from their natal site was unlikely to be possible for several months prior to sampling due to a lack of hydrological connectivity caused by extended cease-to-flow conditions (R.J. Woods and D.A. Crook, personal observations). However, flow occurred dur- 
Table 5. Location of sampling sites and genetic diversity statistics for each population sampled in 2004 (2003 and 2004 cohorts) and 2005 (2004 and 2005 cohorts).

\begin{tabular}{|c|c|c|c|c|c|c|c|c|c|c|c|c|c|}
\hline \multirow[b]{3}{*}{ Sampling site } & \multirow[b]{3}{*}{ Location } & \multicolumn{9}{|c|}{2004} & \multirow{2}{*}{\multicolumn{3}{|c|}{$\begin{array}{l}2005 \\
\text { Microsatellites }\end{array}$}} \\
\hline & & \multicolumn{3}{|c|}{ Allozymes } & \multicolumn{3}{|c|}{ Microsatellites } & \multicolumn{3}{|c|}{ mtDNA } & & & \\
\hline & & $n$ & $\mathrm{Ar}$ & $H_{\mathrm{e}}$ & $n$ & $\mathrm{Ar}$ & $H_{\mathrm{e}}$ & $n$ & $n_{\text {hap }}$ & $h$ & $n$ & $\mathrm{Ar}$ & $H_{\mathrm{e}}$ \\
\hline \multicolumn{14}{|c|}{ Campaspe catchment } \\
\hline Campaspe River & $36^{\circ} 15^{\prime} \mathrm{S}, 144^{\circ} 44^{\prime} \mathrm{E}$ & 30 & 2.8 & 0.26 & 30 & 10.75 & 0.71 & 20 & 9 & $0.87 \pm 0.04$ & 20 & 8.83 & 0.87 \\
\hline Forest Creek & $36^{\circ} 39^{\prime} \mathrm{S}, 144^{\circ} 33^{\prime} \mathrm{E}$ & 30 & 3.0 & 0.32 & 30 & 9.50 & 0.77 & 20 & 5 & $0.56 \pm 0.11$ & - & - & - \\
\hline McIvor Creek & $36^{\circ} 56^{\prime} \mathrm{S}, 144^{\circ} 43^{\prime} \mathrm{E}$ & 30 & 2.4 & 0.29 & 30 & 9.25 & 0.74 & 20 & 5 & $0.66 \pm 0.09$ & 20 & 7.18 & 0.66 \\
\hline \multicolumn{14}{|c|}{ Goulburn catchment } \\
\hline Broken River & $36^{\circ} 28^{\prime} \mathrm{S}, 145^{\circ} 53^{\prime} \mathrm{E}$ & 30 & 2.0 & 0.22 & 30 & 10.25 & 0.77 & 20 & 10 & $0.91 \pm 0.03$ & 20 & 6.51 & 0.80 \\
\hline Castle Creek & $36^{\circ} 37^{\prime} \mathrm{S}, 145^{\circ} 22^{\prime} \mathrm{E}$ & 30 & 2.6 & 0.28 & 30 & 11.25 & 0.76 & 20 & 8 & $0.69 \pm 0.10$ & 19 & 6.73 & 0.77 \\
\hline Dabyminga Creek & $37^{\circ} 06^{\prime} \mathrm{S}, 145^{\circ} 07^{\prime} \mathrm{E}$ & 30 & 2.0 & 0.20 & 30 & 6.25 & 0.67 & 20 & 4 & $0.55 \pm 0.11$ & 20 & 6.63 & 0.81 \\
\hline Reedy Lake Creek & $36^{\circ} 44^{\prime} \mathrm{S}, 145^{\circ} 07^{\prime} \mathrm{E}$ & 30 & 2.4 & 0.28 & 30 & 11.00 & 0.78 & 20 & 10 & $0.86 \pm 0.05$ & 20 & 6.48 & 0.82 \\
\hline Seven Creeks & $36^{\circ} 36^{\prime} \mathrm{S}, 145^{\circ} 29^{\prime} \mathrm{E}$ & 30 & 2.6 & 0.26 & 30 & 8.50 & 0.72 & 20 & 5 & $0.51 \pm 0.12$ & 20 & 7.85 & 0.82 \\
\hline Sugarloaf Creek & $37^{\circ} 04^{\prime} \mathrm{S}, 145^{\circ} 03^{\prime} \mathrm{E}$ & 30 & 2.2 & 0.36 & 30 & 6.25 & 0.51 & 20 & 5 & $0.66 \pm 0.09$ & 20 & 4.75 & 0.61 \\
\hline Glen Creek & $36^{\circ} 19^{\prime} \mathrm{S}, 145^{\circ} 20^{\prime} \mathrm{E}$ & 30 & 2.4 & 0.42 & 30 & 10.25 & 0.80 & 20 & 9 & $0.84 \pm 0.06$ & - & - & - \\
\hline \multicolumn{14}{|l|}{ Ovens catchment } \\
\hline Croppers Creek & $36^{\circ} 27^{\prime} \mathrm{S}, 146^{\circ} 22^{\prime} \mathrm{E}$ & 30 & 2.4 & 0.26 & 30 & 11.00 & 0.76 & 20 & 10 & $0.71 \pm 0.11$ & 20 & 7.31 & 0.81 \\
\hline Hurdle Creek & $36^{\circ} 31^{\prime} \mathrm{S}, 146^{\circ} 25^{\prime} \mathrm{E}$ & 30 & 2.4 & 0.27 & 30 & 10.75 & 0.79 & 20 & 13 & $0.91 \pm 0.05$ & 20 & 8.29 & 0.87 \\
\hline Reedy Creek & $36^{\circ} 20^{\prime} \mathrm{S}, 146^{\circ} 21^{\prime} \mathrm{E}$ & 30 & 2.8 & 0.26 & 30 & 10.75 & 0.76 & 20 & 10 & $0.83 \pm 0.07$ & 20 & 6.94 & 0.75 \\
\hline
\end{tabular}

Note: Ar, allelic richness; $H_{\mathrm{e}}$, expected heterozygosity; $n_{\text {hap }}$, number of unique haplotypes sampled within a population; $h$, haplotype diversity. 
Table 6. Analysis of molecular variance to test for hierarchical structuring of genetic variation in the 2004 sample.

\begin{tabular}{|c|c|c|c|}
\hline Locus & $\begin{array}{l}\text { Among catchments } \\
\left(F_{\mathrm{CT}}\right)\end{array}$ & $\begin{array}{l}\text { Among populations within } \\
\text { catchments }\left(F_{\mathrm{SC}}\right)\end{array}$ & $\begin{array}{l}\text { Among all popula- } \\
\text { tions }\left(F_{\mathrm{ST}}\right)\end{array}$ \\
\hline \multicolumn{4}{|l|}{ Multiple loci } \\
\hline $\begin{array}{l}\text { Microsatellites (four loci com- } \\
\text { bined) }\end{array}$ & 0.002 & $0.043 * * *$ & $0.045^{* * *}$ \\
\hline Allozymes (five loci combined) & 0.003 & $0.093 * * *$ & $0.095 * * *$ \\
\hline \multicolumn{4}{|l|}{ Individual loci } \\
\hline$m t D N A$ & 0.000 & $0.236 * * *$ & $0.213 * * *$ \\
\hline Sm49 & 0.000 & $0.041 * * *$ & $0.037 * * *$ \\
\hline Sm18 & $0.014 *$ & $0.043 * * *$ & $0.056 * * *$ \\
\hline $\operatorname{Sm} 26$ & 0.007 & $0.034 * * *$ & $0.041 * * *$ \\
\hline $\operatorname{Sm} 80$ & 0.000 & $0.055 * * *$ & $0.044 * * *$ \\
\hline$P G I$ & $0.041 *$ & $0.045 * * *$ & $0.085 * * *$ \\
\hline$A A T-1$ & 0.000 & $0.011 * * *$ & 0.006 \\
\hline$A A T-2$ & 0.000 & $0.039^{*}$ & $0.031 *$ \\
\hline$\beta E S T$ & 0.000 & $0.055 * * *$ & $0.047 * * *$ \\
\hline$P E P-B$ & 0.000 & $0.143 * * *$ & $0.127 * * *$ \\
\hline
\end{tabular}

Note: Significance determined by 10000 random permutations of sampling units among predefined hierarchical groupings (i.e., populations among catchments $\left(F_{\mathrm{CT}}\right)$, individuals among populations within catchments $\left(F_{\mathrm{SC}}\right)$, and individuals among populations $\left(F_{\mathrm{ST}}\right) . *, P<0.05 ; * *, P<0.001 ; * * *, P<0.0001$.

ing or immediately prior to sampling at some sites (e.g., Campaspe River), and at least some dispersal of juveniles may have been possible but apparently did not occur to a large extent at most sites.

Sampling of the 2004 cohort of fish as 1-year-olds in 2005 for otolith chemistry analysis was conducted following a period in which all of the study sites had experienced periods of hydrological connection during winter and spring. Unlike the genetic and otolith chemistry results for the 2004 samples, the core otolith chemistry assignment tests suggested that retention of 1-year-old individuals was highly variable among sites in 2005. Given the similarities in otolith core chemistry of YOY fish collected in 2004 at some sites across the different catchments, some potential exists for our retention estimates to be biased by intercatchment immigration during the periods of hydrologic connection. However, the large geographic distance among the catchments, the presence of numerous instream barriers, and the relatively short duration of reconnection during winter and spring 2004 suggest that such large-scale movements are unlikely to strongly influence our findings. Overall, the otolith chemistry results suggest that dispersal of smelt may be both spatially and temporally variable and that hydrologic connectivity is likely to be a major factor in determining the rates of dispersal within catchments. Likewise, the genetic analysis of 2005 fish showed greater among-site variation in assignment success relative to the 2004 sample. It is notable that otolith chemistry indicated high retention of 1-year-old individuals in the Campaspe and Ovens catchments but more variation in the Goulburn catchment. A similar pattern was reflected in the genetic assignment results. Populations in the Goulburn catchment had consistently high rates of genetic assignment success in 2004 (ranging from 93\% to $100 \%)$, with more variation evident in $2005(75 \%-100 \%)$. Although otolith chemistry and genetic analysis of smelt were each able to detect similar patterns of spatial population structure in 2004, the response to connectivity in 2005 was more noticeable in the otolith analysis. The difference in resolving power of the two methods might be explained by more pronounced variation in water chemistry over small spatial scales relative to variation in population allele frequencies. An increase in power to correctly detect immigrant individuals using the genetic approach would be achievable with the use of more microsatellite loci (Paetkau et al. 2004).

\section{Historical dispersal}

Analysis of otolith and genetic data at the level of individual populations indicates limited contemporary dispersal of smelt during periods of low hydrological connectivity and spatially variable dispersal following higher flows that reinstate connectivity. Although the otolith chemistry results suggest that immigrants moved into many of the study sites between the summer of 2004 and the summer of 2005, this provides no information on the distance moved by individuals, and thus, we are unable to determine the spatial extent of contemporary connectivity between local populations from the otolith chemistry data. Nevertheless, if the presentday dispersal is spatially restricted and this is indicative of a long-term historical pattern, we might expect partitioning of genetic variation among the three catchments to be relatively large and significantly nonrandom in accordance with the stream hierarchy model (Meffe and Vrijenhoek 1988). Similarly, if equilibrium between limited migration and genetic drift were established throughout the study region, then a positive correlation would be expected between population differentiation and river distance (Slatkin 1993; Hutchison and Templeton 1999). As neither of these models was supported by the genetic data, we infer that (i) longterm equilibrium between drift and migration is not established and (or) (ii) that the observed spatial pattern of differentiation is the product of stochastic sorting of genetic variation into the refugial pools that form during dry periods of the year. The latter hypothesis (ii) is analogous to 
Fig. 4. Isolation-by-distance scatterplots showing relationship between genetic differentiation and geographic distance for all pairwise combinations of 13 population samples collected in 2004: (a) mtDNA data set; (b) allozyme data set; and (c) microsatellite data set.
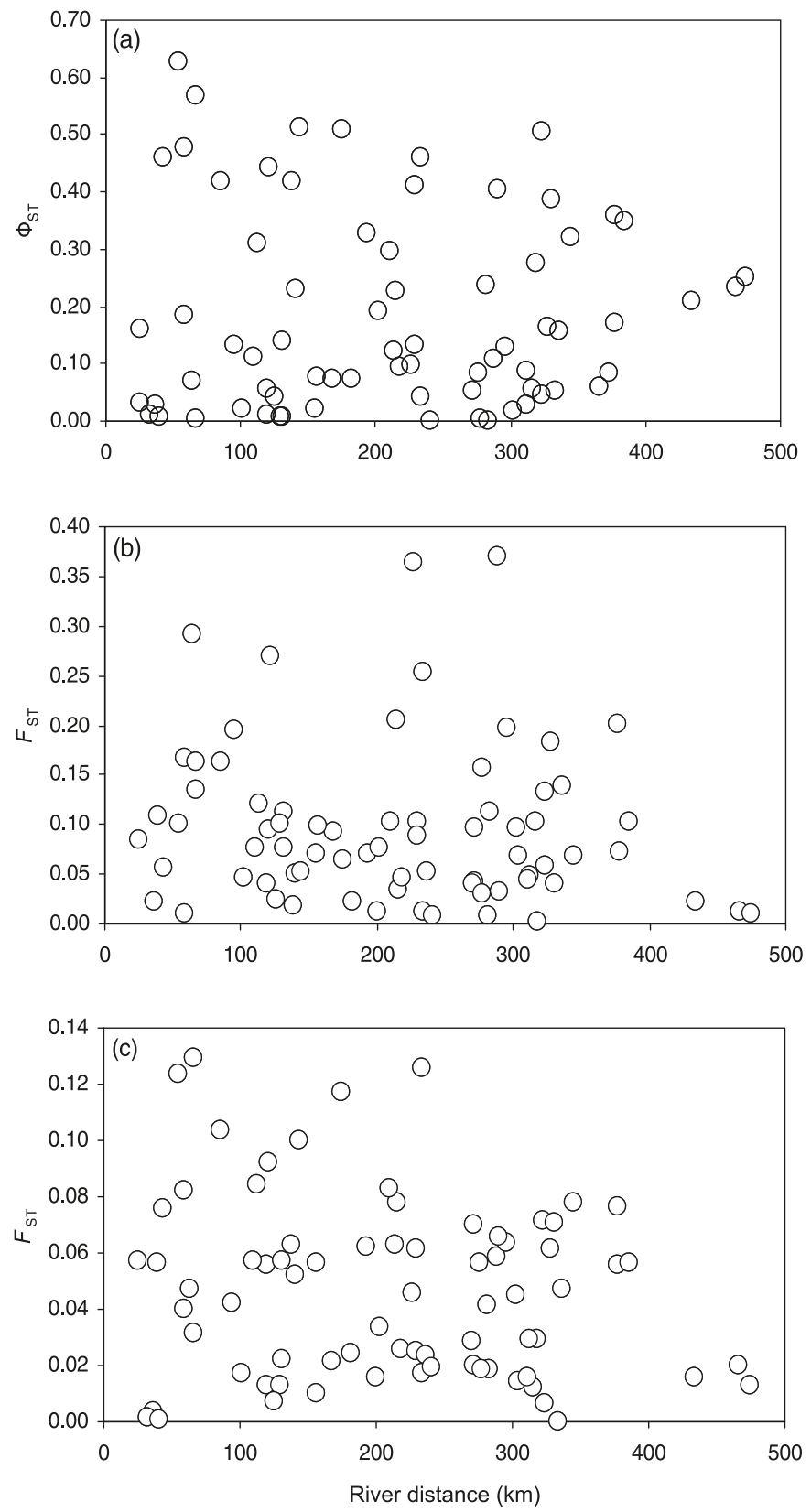

"patchy recruitment" (sensu Bunn and Hughes 1997) or "family sampling" (sensu Allendorf and Phelps 1981) whereby a sample of individuals is representative of a limited number of families rather than the wider population. In this way, colonization of refugial pools by closely related cohorts of juvenile smelt at the end of spring and early summer might result in the population-level differentiation observed at small spatial scales. This scenario might be supported by extensive deviations from Hardy-Weinberg proportions across loci and sampling sites due to nonrandom mating (Bunn and Hughes 1997; Hughes et al. 1998). However only a small number of these deviations were observed in the present study, as is typically the case in similar studies of freshwater fish populations (e.g., Huey et al. 2008).

The hypothesis of nonequilibrium between migration and genetic drift across the study area (i.e., hypothesis $i$, above) is supported by the observed relationship between river distance and genetic differentiation, which resembles the hypothetical outcome expected when a homogenous source population invades a region, followed by dramatic attenuation of among-population gene flow (Hutchison and Templeton 1999). According to this scenario (i.e., case III, Hutchison and Templeton 1999), the scatter of points in the IBD plot results from stochastic sorting of genetic variation into populations due to rapid colonization of a region, followed by small-scale fragmentation of populations ("microvicariance," Templeton et al. 1990), which increases variance in the differentiation between pairs of populations without regard to the geographic distance separating them. Nonsignificant IBD patterns similar to those observed in this study are occasionally observed in studies of river fish taxa (e.g., Castric et al. 2001; Costello et al. 2003). In these cases, a historically recent colonization of the river system is usually high on the list of suspected biological mechanisms to account for the pattern. Nucleotide variation at the mtDNA locus is compatible with the nonequilibrium hypothesis as this satisfies a model of rapid expansion in population size across the study area occurring during the late Pleistocene. Although it seems clear that a balance between genetic drift and migration has not been reached across the study area, further study is required to establish whether patchy recruitment is contributing to the observed patterns of genetic variation. Analysis of genetic variation over multiple years within sites would be useful to address this question because temporal differentiation would be expected to match or exceed spatial variation if refugial pools are colonized under a model of patchy recruitment (Hughes et al. 1998).

\section{Implications for river management}

It appears that despite evidence of some localized movement, contemporary among-population movement of Australian smelt within the three study catchments is restricted to at least some extent and that this has resulted in genetic structuring among local populations. This finding is particularly interesting in light of previous studies in larger, more perennial lowland rivers that have reported large numbers of Australian smelt undertaking potamodromous migrations through fishways (Mallen-Cooper et al. 1995). Such apparently disparate behaviour by smelt in different environments suggests that connectivity between local and regional populations of this species differs between small ephemeral waterways and larger lowland rivers. This has clear implications for the management of rivers and their fisheries, as it suggests that specialized strategies may be required to conserve the genetic and ecological integrity of populations of a single species depending on the environmental (e.g., hydrological) characteristics of the ecosystem under consideration.

Integrating methods of otolith chemistry and genetic analysis, as demonstrated here, provides a promising means of interpreting the contemporary responses of species to changes in land and water management practices within the 
context of their premanagement history. Given the imminent threats to aquatic biota in ephemeral waterways posed by factors such as predicted climate change and increasing human demands for water, an understanding of contemporary and historical movement patterns of species at the landscape scale is critical to the future development of strategies to conserve biodiversity in aquatic ecosystems.

\section{Acknowledgements}

We thank Damien O'Mahony for help in collecting samples and David Gopurenko and Mark Ponniah for assistance in the lab. Funding was provided by eWater CRC, CRC for Freshwater Ecology, Australian Rivers Institute, Griffith University School of Environmental Science, and an Australian Postgraduate Award (R.J.W.). Procedures were carried out in accordance with Australian Ethics Approval No. AES 03/04/AEC.

\section{References}

Allendorf, F.W., and Phelps, S.R. 1981. Use of allelic frequencies to describe population structure. Can. J. Fish. Aquat. Sci. 38(12): 1507-1514. doi:10.1139/f81-203.

Avise, J.C. 2004. Molecular markers, natural history, and evolution. Sinauer Associates, Inc., Sunderland, Massachusetts.

Baerwald, M., Bien, V., Feyrer, F., and May, B. 2007. Genetic analysis reveals two distinct Sacramento splittail (Pogonichthys macrolepidotus) populations. Conserv. Genet. 8(1): 159-167. doi:10.1007/s10592-006-9157-2.

Barbee, N.C., and Swearer, S.E. 2007. Characterizing natal source population signatures in the diadromous fish Galaxias maculatus, using embryonic otolith chemistry. Mar. Ecol. Prog. Ser. 343: 273-282. doi: 10.3354/meps06886.

Baumgartner, L.J. 2004. The effects of Balranald Weir on spatial and temporal distributions of lower Murrumbidgee River fish assemblages. Final Report Series No. 65, NSW Fisheries, Cronulla, Australia.

Benjamini, Y., and Yekutieli, D. 2001. The control of the false discovery rate in multiple testing under dependency. Ann. Stat. 29(4): 1165-1188.

Bermingham, E., McCafferty, S., and Martin, A. 1997. Fish biogeography and molecular clocks: perspectives from the Panamanian Isthmus. In Molecular systematics of fishes. Edited by T. Kocher and C. Stepien. Academic Press, New York. pp. 113-126.

Bradbury, I.R., Campana, S.E., and Bentzen, P. 2008. Estimating contemporary early life-history dispersal in an estuarine fish: integrating molecular and otolith elemental approaches. Mol. Ecol. 17(6): 14381450. doi:10.1111/j.1365-294X.2008.03694.x. PMID:18321254.

Bunn, S.E., and Hughes, J.M. 1997. Dispersal and recruitment in streams: evidence from genetic studies. J. N. Am. Benthol. Soc. 16(2): 338-346. doi:10.2307/1468022.

Campana, S.E. 1999. Chemistry and composition of fish otoliths: pathways, mechanisms and applications. Mar. Ecol. Prog. Ser. 188: 263-297. doi:10.3354/meps188263.

Campana, S.E., Thorrold, S.R., Jones, C.M., Günther, D., Tubrett, M., Longerich, H., Jackson, S., Haldon, N.M., Kalish, J.M., Piccoli, P., de Pontual, H., Troadec, H., Panfili, J., Secor, D.H., Severin, K.P., Sie, S.H., Thresher, R., Teesdale, W.J., and Campbell, J.L. 1997. Comparison of accuracy, precision, and sensitivity in elemental assays of fish otoliths using electron microprobe, proton-induced X-ray emission, and laser ablation inductively coupled plasma mass spectrometry. Can. J. Fish. Aquat. Sci. 54(9): 2068-2079. doi:10.1139/cjfas-54-9-2068.
Castric, V., Bonney, F., and Bernatchez, L. 2001. Landscape structure and hierarchical genetic diversity in the brook charr, Salvelinus fontinalis. Evolution, 55(5): 1016-1028. doi:10.1554/00143820(2001)055[1016:LSAHGD]2.0.CO;2. PMID:11430638.

Clarke, A.D., Telmer, K.H., and Shrimpton, J.M. 2007. Habitat use and movement patterns for a fluvial species, the Arctic grayling, in a watershed impacted by a large reservoir: evidence from otolith microchemistry. J. Appl. Ecol. 44(6): 1156-1165. doi:10. 1111/j.1365-2664.2007.01350.x.

Commonwealth Scientific and Industrial Research Organisation and Australian Bureau of Meteorology. 2007. Climate change in Australia: technical report 2007. Commonwealth Scientific and Industrial Research Organisation (CSIRO), Canberra, Australia.

Costello, A.B., Down, T.E., Pollard, S.M., Pacas, C.J., and Taylor, E.B. 2003. The influence of history and contemporary stream hydrology on the evolution of genetic diversity within species: an examination of microsatellite DNA variation in bull trout, Salvelinus confluentus (Pisces: Salmonidae). Evolution, 57(2): 328-344. PMID:12683529.

Crook, D.A., and Gillanders, B.M. 2006. Use of otolith chemical signatures to estimate carp recruitment sources in the mid-Murray River, Australia. River Res. Appl. 22(8): 871-879. doi:10.1002/ rra.941.

Crook, D.A., Macdonald, J.I., and Raadik, T.A. 2008. Evidence of diadromous movements in a coastal population of southern smelts (Retropinninae: Retropinna) from Victoria, Australia. Mar. Freshw. Res. 59(7): 638-646. doi:10.1071/MF07238.

Doyle, J.J., and Doyle, J.L. 1987. A rapid DNA isolation procedure for small quantities of fresh leaf tissue. Phytochem. Bull. 19: 11-15.

Eggins, S.M., and Shelley, J.M.G. 2002. Compositional heterogeneity in NIST SRM 610-617 glasses. Geostand. Newsl. 26(3): 269-286. doi:10.1111/j.1751-908X.2002.tb00634.x.

Eggins, S.M., Kinsley, L.P.J., and Shelley, J.M.G. 1998. Deposition and element fractionation processes during atmospheric pressure laser sampling for analysis by ICPMS. Appl. Surf. Sci. 127129(1-2): 278-286. doi:10.1016/S0169-4332(97)00643-0.

Eggins, S.M., Grün, R., McCulloch, M.T., Pike, A.W.G., Chappell, J., Kinsley, L., Mortimer, G., Shelley, M., Murray-Wallace, C.V., Spötl, C., and Taylor, L. 2005. In situ U-series dating by laser-ablation multi-collector ICP-MS: new prospects for Quaternary geochronology. Quat. Sci. Rev. 24(23-24): 2523-2538. doi:10.1016/j.quascirev.2005.07.006.

Excoffier, L., Laval, G., and Schneider, S. 2005. Arlequin (version 3.0): an integrated software package for population genetics data analysis. Evol. Bioinform. Online, 1: 47-50. PMID:19325852.

Fagan, W.F. 2002. Connectivity, fragmentation, and extinction risk in dendritic metapopulations. Ecology, 83(12): 3243-3249. doi:10.1890/0012-9658(2002)083[3243:CFAERI]2.0.CO;2.

Fetzner, J.W., Jr., and Crandall, K.A. 2003. Linear habitats and the nested clade analysis: an empirical evaluation of geographic versus river distances using an Ozark crayfish (Decapoda: Cambaridae). Evolution, 57(9): 2101-2118. PMID:14575330.

Feyrer, F., Hobbs, J., Baerwald, M., Sommer, T., Yin, Q.Z., Clark, K., May, B., and Bennett, W. 2007. Otolith microchemistry provides information complementary to microsatellite DNA for a migratory fish. Trans. Am. Fish. Soc. 136(2): 469-476. doi:10. 1577/T06-044.1.

Forrester, G.E., and Swearer, S.E. 2002. Trace elements in otoliths indicate the use of open-coast versus bay nursery habitats by juvenile California halibut. Mar. Ecol. Prog. Ser. 241: 201-213. doi: $10.3354 /$ meps 241201.

Fu, Y.X. 1997. Statistical tests of neutrality of mutations against population growth, hitchhiking and background selection. Genetics, 147(2): 915-925. PMID:9335623. 
Gillanders, B.M. 2002. Connectivity between juvenile and adult fish populations: do adults remain near their recruitment estuaries? Mar. Ecol. Prog. Ser. 240: 215-223. doi:10.3354/ meps240215.

Gillanders, B.M., and Joyce, T.C. 2005. Distinguishing aquaculture and wild yellowtail kingfish via natural elemental signatures in otoliths. Mar. Freshw. Res. 56(5): 693-704. doi:10.1071/ MF04133.

Grant, E.H.C., Lowe, W.H., and Fagan, W.F. 2007. Living in the branches: population dynamics and ecological processes in dendritic networks. Ecol. Lett. 10(2): 165-175. doi:10.1111/j.14610248.2006.01007.x. PMID:17257104.

Hall, T.A. 1999. BioEdit: a user-friendly biological sequence alignment editor and analysis program for Windows 95/98/NT. Nucleic Acids Symp. Ser. 41: 95-98.

Hammer, M.P., Adams, M., Unmack, P.J., and Walker, K.F. 2007. A rethink on Retropinna: conservation implications of new taxa and significant genetic sub-structure in Australian smelts (Pisces: Retropinnidae). Mar. Freshw. Res. 58(4): 327-341. doi:10.1071/MF05258.

Haney, R.A., Silliman, B.R., and Rand, D.M. 2007. A multi-locus assessment of connectivity and historical demography in the bluehead wrasse (Thalassoma bifasciatum). Heredity, 98(5): 294-302. doi:10.1038/sj.hdy.6800940. PMID:17268481.

Hillyer, M.J., Woods, R.J., and Hughes, J.M. 2006. Isolation and characterization of polymorphic microsatellite loci in the Australian smelt, Retropinna semoni. Mol. Ecol. Notes, 6(1): 224-226. doi:10.1111/j.1471-8286.2005.01200.x.

Huey, J.A., Baker, A.M., and Hughes, J.M. 2008. The effect of landscape processes upon gene flow and genetic diversity in an Australian freshwater fish, Neosilurus hyrtlii. Freshw. Biol. 53(7): 1393-1408. doi:10.1111/j.1365-2427.2008.01971.x.

Hughes, J.M. 2007. Constraints on recovery: using molecular methods to study connectivity of aquatic biota in rivers and streams. Freshw. Biol. 52(4): 616-631. doi:10.1111/j.1365-2427.2006. 01722.x.

Hughes, J.M., and Hillyer, M.J. 2006. Mitochondrial DNA and allozymes reveal high dispersal abilities and historical movement across drainage boundaries in two species of freshwater fishes from inland rivers in Queensland, Australia. J. Fish Biol. 68(SB): 270-291. doi:10.1111/j.0022-1112.2006.01073.x.

Hughes, J.M., Bunn, S.E., Hurwood, D.A., and Cleary, C. 1998. Dispersal and recruitment of Tasiagma ciliata (Trichoptera: Tasimiidae) in rainforest streams, south-eastern Australia. Freshw. Biol. 39(1): 117-127. doi:10.1046/j.1365-2427.1998.00268.x.

Hughes, J.M., Schmidt, D.J., and Finn, D.S. 2009. Genes in streams: using DNA to understand the movement of freshwater fauna and their riverine habitat. Bioscience, 59(7): 573-583. doi:10.1525/bio.2009.59.7.8.

Hutchison, D.W., and Templeton, A.R. 1999. Correlation of pairwise genetic and geographic distance measures: inferring the relative influences of gene flow and drift on the distribution of genetic variability. Evolution, 53(6): 1898-1914. doi:10.2307/ 2640449.

Lassalle, G., Béguer, M., Beaulaton, L., and Rochard, E. 2008. Diadromous fish conservation plans need to consider global warming issues: an approach using biogeographical models. Biol. Conserv. 141(4): 1105-1118. doi:10.1016/j.biocon.2008. 02.010 .

Lucas, M.C., and Baras, E. 2000. Methods for studying spatial behaviour of freshwater fishes in the natural environment. Fish Fish. 1: 283-316.

Macdonald, J.I., Shelley, J.M.G., and Crook, D.A. 2008. A method for improving the estimation of natal chemical signatures in oto- liths. Trans. Am. Fish. Soc. 137(6): 1674-1682. doi:10.1577/ T07-249.1.

Mallen-Cooper, M. 1999. Developing fishways for nonsalmonid fishes: a case study from the Murray River in Australia. In Innovations in fish passage technology. Edited by M. Odeh. American Fisheries Society, Bethesda, Maryland. pp. 173-195.

Mallen-Cooper, M., Stuart, I.G., Hides-Pearson, F., and Harris, J.H. 1995. Migration in the Murray River and assessment of the Torrumbarry Fishway. NSW Fisheries and CRC for Freshwater Ecology, Cronulla, NSW, Australia.

Manel, S., Gaggiotti, O.E., and Waples, R.S. 2005. Assignment methods: matching biological questions with appropriate techniques. Trends Ecol. Evol. 20(3): 136-142. doi:10.1016/j.tree. 2004.12.004. PMID:16701357.

Mantel, N. 1967. The detection of disease clustering and a generalized regression approach. Cancer Res. 27(2): 209-220. PMID: 6018555.

McDowall, R.M. 1988. Diadromy in fishes: migrations between freshwater and marine environments. Croom Helm, London, UK.

McGlashan, D.J., and Hughes, J.M. 2000. Reconciling patterns of genetic variation with stream structure, earth history and biology in the Australian freshwater fish Craterocephalus stercusmuscarum (Atherinidae). Mol. Ecol. 9(11): 1737-1751. doi:10.1046/ j.1365-294x.2000.01054.x. PMID:11091310.

Meffe, G.K., and Vrijenhoek, R.C. 1988. Conservation genetics in the management of desert fishes. Conserv. Biol. 2(2): 157-169. doi:10.1111/j.1523-1739.1988.tb00167.x.

Miles, E.L., Snover, A.K., Hamlet, A.F., Callahan, B., and Fluharty, D. 2000. Pacific Northwest regional assessment: the impacts of climate variability and climate change on the water resources of the Columbia River Basin. J. Am. Water Resour. Assoc. 36(2): 399-420. doi:10.1111/j.1752-1688.2000.tb04277.x.

Millar, R.B. 1990. A versatile computer program for mixed stock fishery composition estimation. Can. Tech. Rep. Fish. Aquat. Sci. No. 1753.

Miller, J.A., Banks, M.A., Gomez-Uchida, D., and Shanks, A.L. 2005. A comparison of population structure in black rockfish (Sebastes melanops) as determined with otolith microchemistry and microsatellite DNA. Can. J. Fish. Aquat. Sci. 62(10): 21892198. doi:10.1139/f05-133.

Miller, J.A., Bellinger, M.R., Golden, J.T., Fujishin, L., and Banks, M.A. 2010. Integration of natural and artificial markers in a mixed stock analysis of Chinook salmon (Oncorhynchus tshawytscha). Fish. Res. 102(1-2): 152-159. doi:10.1016/j.fishres. 2009.11.005.

Mimikou, M.A., Baltas, E., Varanou, E., and Pantazis, K. 2000. Regional impacts of climate change on water resources quantity and quality indicators. J. Hydrol. (Amst.), 234(1-2): 95-109. doi:10.1016/S0022-1694(00)00244-4.

Narum, S.R. 2006. Beyond Bonferroni: less conservative analyses for conservation genetics. Conserv. Genet. 7(5): 783-787. doi:10.1007/s10592-005-9056-y.

Paetkau, D., Slade, R., Burden, M., and Estoup, A. 2004. Genetic assignment methods for the direct, real-time estimation of migration rate: a simulation-based exploration of accuracy and power. Mol. Ecol. 13(1): 55-65. doi:10.1046/j.1365-294X.2004. 02008.x. PMID:14653788.

Piry, S., Alapetite, A., Cornuet, J.M., Paetkau, D., Baudouin, L., and Estoup, A. 2004. GENECLASS2: a software for genetic assignment and first-generation migrant detection. J. Hered. 95(6): 536-539. doi:10.1093/jhered/esh074. PMID:15475402.

Pusey, B., Kennard, M., and Arthington, A. 2004. Freshwater fishes of north-eastern Australia. CSIRO Publishing, Collingwood, Victoria, Australia. 
Ramos-Onsins, S.E., and Rozas, J. 2002. Statistical properties of new neutrality tests against population growth. Mol. Biol. Evol. 19(12): 2092-2100. PMID:12446801.

Rannala, B., and Mountain, J.L. 1997. Detecting immigration by using multilocus genotypes. Proc. Natl. Acad. Sci. U.S.A. 94(17): 9197-9201. doi:10.1073/pnas.94.17.9197. PMID:9256459.

Raymond, M., and Rousset, F. 1995. GENEPOP, version 1.2: population genetics software for exact tests and ecumenism. J. Hered. 86: 248-249.

Richardson, B.J., Baverstock, P.R., and Adams, M. 1986. Allozyme electrophoresis: a handbook for animal systematics and population studies. Academic Press, Sydney, Australia.

Rogers, A.R. 1995. Genetic evidence for a Pleistocene population explosion. Evolution, 49(4): 608-615. doi:10.2307/2410314.

Rozas, J., Sánchez-DelBarrio, J.C., Messeguer, X., and Rozas, R. 2003. DnaSP, DNA polymorphism analyses by the coalescent and other methods. Bioinformatics, 19(18): 2496-2497. doi:10. 1093/bioinformatics/btg359. PMID:14668244.

Ruttenberg, B.I., and Warner, R.R. 2006. Spatial variation in the chemical composition of natal otoliths from a reef fish in the Galápagos Islands. Mar. Ecol. Prog. Ser. 328: 225-236. doi:10. 3354/meps328225.

Sandin, S.A., Regetz, J., and Hamilton, S.L. 2005. Testing larval fish dispersal hypotheses using maximum likelihood analysis of otolith chemistry data. Mar. Freshw. Res. 56(5): 725-734. doi:10.1071/MF04144.

Slatkin, M. 1993. Isolation by distance in equilibrium and nonequilibrium populations. Evolution, 47(1): 264-279. doi:10.2307/ 2410134.
Slatkin, M. 1995. A measure of population subdivision based on microsatellite allele frequencies. Genetics, 139(1): 457-462. PMID:7705646.

Stamford, M.D., and Taylor, E.B. 2005. Population subdivision and genetic signatures of demographic changes in Arctic grayling (Thymallus arcticus) from an impounded watershed. Can. J. Fish. Aquat. Sci. 62(11): 2548-2559. doi:10.1139/f05-156.

Swearer, S.E., Caselle, J.E., Lea, D.W., and Warner, R.R. 1999. Larval retention and recruitment in an island population of a coral-reef fish. Nature (London), 402(6763): 799-802. doi:10. $1038 / 45533$.

Templeton, A.R., Shaw, K., Routman, E., and Davis, S.K. 1990. The genetic consequences of habitat fragmentation. Ann. Mo. Bot. Gard. 77(1): 13-27. doi:10.2307/2399621.

Thorrold, S.R., Latkoczy, C., Swart, P.K., and Jones, C.M. 2001. Natal homing in a marine fish metapopulation. Science (Washington, D.C.), 291(5502): 297-299. doi:10.1126/science.291. 5502.297. PMID:11209078.

Waters, J.M., Saruwatari, T., Kobayashi, T., Oohara, I., McDowall, R.M., and Wallis, G.P. 2002. Phylogenetic placement of retropinnid fishes: data set incongruence can be reduced by using asymmetric character state transformation costs. Syst. Biol. 51(3): 432-449. doi:10.1080/10635150290069887. PMID: 12079643.

White, J.W., and Ruttenberg, B.I. 2007. Discriminant function analysis in marine ecology: some oversights and their solutions. Mar. Ecol. Prog. Ser. 329: 301-305. doi:10.3354/meps329301.

\section{Appendix A}

Table A1. mtDNA haplotype codes and their sample frequency at each site.

\begin{tabular}{|c|c|c|c|c|c|c|c|c|c|c|c|c|c|c|}
\hline & GenBank no. & $\mathrm{CR}$ & $\mathrm{FC}$ & $\mathrm{MC}$ & $\mathrm{BR}$ & $\mathrm{CA}$ & DC & RL & SE & $\mathrm{SC}$ & GL & $\mathrm{CC}$ & $\mathrm{HC}$ & $\mathrm{RE}$ \\
\hline Hap1 & FJ593511 & 5 & 13 & 3 & 1 & 11 & 4 & 5 & 14 & & 4 & 11 & 6 & 8 \\
\hline Hap2 & FJ593512 & 5 & & 1 & 4 & 3 & & 2 & 2 & & 1 & 1 & 1 & 3 \\
\hline Hap3 & FJ593513 & & & 1 & & 1 & & & & & & & & \\
\hline Hap4 & FJ593514 & 2 & 1 & 11 & & & 13 & & 1 & & & & & \\
\hline Hap5 & FJ593515 & & & 4 & & & & & & & & & & \\
\hline Hap6 & FJ593516 & 3 & 3 & & 2 & & & 1 & & 3 & & & 3 & 2 \\
\hline Hap7 & FJ593517 & & 1 & & & & & & & & & & & \\
\hline Hap8 & FJ593518 & & 2 & & & & & & & & 1 & & & \\
\hline Hap9 & FJ593519 & 1 & & & & & & & & & & & & \\
\hline Hap10 & FJ593520 & 1 & & & 1 & 1 & & & & & & & & \\
\hline Hap11 & FJ593521 & 1 & & & & & & & & & & & & \\
\hline Hap12 & FJ593522 & 1 & & & & & & & & & & & & \\
\hline Hap13 & FJ593523 & 1 & & & & & & & & & & & & \\
\hline Hap14 & FJ593524 & & & & 2 & 1 & & & & & & & & 1 \\
\hline Hap15 & FJ593525 & & & & 4 & 1 & 2 & 6 & & & 7 & 1 & & 1 \\
\hline Hap16 & FJ593526 & & & & 3 & & & & & & & & & \\
\hline Hap17 & FJ593527 & & & & 1 & & & & & & & & & \\
\hline Hap18 & FJ593528 & & & & 1 & & & & & & & & & \\
\hline Hap19 & FJ593529 & & & & 1 & & & & & & & & 1 & \\
\hline Hap20 & FJ593530 & & & & & & & & 1 & & & & & \\
\hline Hap21 & FJ593531 & & & & & & & & 2 & & & & & \\
\hline Hap22 & FJ593532 & & & & & 1 & & & & & & & & \\
\hline Hap23 & FJ593533 & & & & & 1 & & 1 & & 4 & 1 & & & 1 \\
\hline Hap24 & FJ593534 & & & & & & & & & 11 & & & & \\
\hline Hap25 & FJ593535 & & & & & & & & & 1 & & & & \\
\hline Hap26 & FJ593536 & & & & & & & & & 1 & & & & \\
\hline
\end{tabular}


Table A1 (concluded).

\begin{tabular}{|c|c|c|c|c|c|c|c|c|c|c|c|c|c|c|}
\hline & GenBank no. & CR & $\mathrm{FC}$ & $\mathrm{MC}$ & BR & $\mathrm{CA}$ & $\mathrm{DC}$ & RL & SE & $\mathrm{SC}$ & GL & $\mathrm{CC}$ & $\mathrm{HC}$ & $\mathrm{RE}$ \\
\hline Hap27 & FJ593537 & & & & & & 1 & & & & & & & \\
\hline Hap28 & FJ593538 & & & & & & & 1 & & & & & & \\
\hline Hap29 & FJ593539 & & & & & & & 1 & & & & & & \\
\hline Hap30 & FJ593540 & & & & & & & 1 & & & & & & \\
\hline Hap31 & FJ593541 & & & & & & & 1 & & & & 1 & 1 & \\
\hline Hap32 & FJ593542 & & & & & & & 1 & & & & & & \\
\hline Hap33 & FJ593543 & & & & & & & & & & 1 & 1 & & 1 \\
\hline Hap34 & FJ593544 & & & & & & & & & & 3 & & & \\
\hline Hap35 & FJ593545 & & & & & & & & & & 1 & & & \\
\hline Hap36 & FJ593546 & & & & & & & & & & 1 & & & \\
\hline Hap37 & FJ593547 & & & & & & & & & & & & & 1 \\
\hline Hap38 & FJ593548 & & & & & & & & & & & & 1 & 1 \\
\hline Hap39 & FJ593549 & & & & & & & & & & & & & 1 \\
\hline Hap40 & FJ593550 & & & & & & & & & & & 1 & & \\
\hline Hap41 & FJ593551 & & & & & & & & & & & 1 & & \\
\hline Hap42 & FJ593552 & & & & & & & & & & & 1 & & \\
\hline Hap43 & FJ593553 & & & & & & & & & & & 1 & & \\
\hline Hap44 & FJ593554 & & & & & & & & & & & 1 & & \\
\hline Hap45 & FJ593555 & & & & & & & & & & & & 1 & \\
\hline Hap46 & FJ593556 & & & & & & & & & & & & 1 & \\
\hline Hap47 & FJ593557 & & & & & & & & & & & & 1 & \\
\hline Hap48 & FJ593558 & & & & & & & & & & & & 1 & \\
\hline Hap49 & FJ593559 & & & & & & & & & & & & 1 & \\
\hline Hap50 & FJ593560 & & & & & & & & & & & & 1 & \\
\hline Hap51 & FJ593561 & & & & & & & & & & & & 1 & \\
\hline Total & & 20 & 20 & 20 & 20 & 20 & 20 & 20 & 20 & 20 & 20 & 20 & 20 & 20 \\
\hline
\end{tabular}

Note: Site codes: CR, Campaspe River; FC, Forest Creek; MC, McIvor Creek; BR, Broken River; CA, Castle Creek; DC, Dabyminga Creek; RL, Reedy Lake Creek; SE, Seven Creeks; SC, Sugarloaf Creek; GL, Glen Creek; CC, Castle Creek; HC, Hurdle Creek; RC, Reedy Creek. 